\title{
Malolos Heritage District: A cultural heritage mapping and inventory - 2020-2021
}

\author{
Arch. Dennis L. Estacio *, Arch. Ma Teresa V. Gopez, and Arch Ma. Saturnina C. Parungao \\ Architecture Department, College of Architecture and Fine Arts, Bulacan State University, City of Malolos, Bulacan, \\ Philippines, 3000
}

Global Journal of Engineering and Technology Advances, 2021, 08(03), 062-086

Publication history: Received on 08 August 2021; revised on 21 September 2021; accepted on 23 September 2021

Article DOI: https://doi.org/10.30574/gjeta.2021.8.3.0129

\begin{abstract}
In the past, Cultural Mapping and Inventory has been used as a technique by some professionals in the 'Community Development' sector as a way of 'Mapping' community assets. How it was undertaken was largely dependent on who was doing it and why, most commonly it was used as a tool to identify the resources of communities and was referred to as 'Community Mapping'. If one were to ask what is Cultural Mapping we would firstly have to say that it involves mapping the Culture of who or what you are, be it a tribe, organization, community, group, school, association, business or an individual - to find your unique assets or strengths. Culture can in this case be defined as your intellectual property, your special way of being or doing, the purpose of your existence, the business you are in (or would like to be) or the special story that you have to tell, such as your reason for doing what you do. It is a process that has a purpose, and through the use of a proven 'system' Cultural Mapping outcomes can be harnessed and directed to create sustainable futures. Cultural mapping and inventory are an ongoing process. And many of its benefits can only be achieved through sustained efforts to update the cultural data and to compare it over time. Because of this, a need to comprehensively consolidate local culture profile and generate baseline data for cultural statistics of Malolos since it was Declared Heritage District in 2001. There would be comprehensive and detailed mapping and inventory that will be produced to serve as guide for validation of the remaining cultural heritage of Malolos that still survive amidst the surging urbanization of Malolos. The consolidated local culture profile and generate baseline data for cultural statistics that will recommend mechanisms to integrate profiles and baseline statistics in LGU development plans, programs, and activities.
\end{abstract}

Keywords: Mapping; Inventory; Heritage; Culture

\section{Rationale}

Cultural mapping is briefly defined as "a systematic approach to identifying, documenting and analyzing a community's cultural resources" [1]. The Cultural Heritage mapping and inventory, more than an academic requirement, is an advocacy-driven initiative that is hoping to affect historical consciousness, promotion of cultural education and socioeconomic development among its stakeholders and the larger community. The City of Malolos is one of the most historic places in the Philippines. Malolos became famous because of its historical and cultural sites like the Barasoain Church, the Spanish and American Era Houses, and the Casa Real and other iconic and significant edifices where the first Philippine constitution was established and remarkable heroes of history like Marcelo H. Del Pilar that stayed in Malolos. There are numerous historical sites and structures in Malolos that are well preserved and well maintained by the government, but some structures in the Heritage District are not along with it. The Malolos Heritage District's rich architectural details that come from the different eras from the Spanish to Post War Era has to be mapped and properly inventory.

\footnotetext{
* Corresponding author: Dennis L

College of Architecture and Fine Arts, Bulacan State University.
} 
Cultural mapping is an 'action journey' undertaken specifically to identify, investigate or reclaim your strengths, whether corporate or personal. Once you have identified these strengths they can be utilized to create a wide variety of outcomes, as demonstrated by the stories in the Case Studies.

Fundamentally, cultural mapping is defined as "an approach used to identify, record, and use cultural resources and activities for building communities, where communities map what is important to them" [2].

In the past, Cultural Mapping has been used as a technique by some professionals in the 'Community Development' sector as a way of 'Mapping' community assets. How it was undertaken was largely dependent on who was doing it and why, most commonly it was used as a tool to identify the resources of communities and was referred to as 'Community Mapping'. If one were to ask what is Cultural Mapping we would firstly have to say that it involves mapping the Culture of who or what you are, be it a tribe, organization, community, group, school, association, business or an individual - to find your unique assets or strengths. Culture can in this case be defined as your intellectual property, your special way of being or doing, the purpose of your existence, the business you are in (or would like to be) or the special story that you have to tell, such as your reason for doing what you do. It is a process that has a purpose, and through the use of a proven 'system' Cultural Mapping outcomes can be harnessed and directed to create sustainable futures [3].

\section{Background of the Study}

The name of Malolos was presumably derived from the Tagalog word "Paluslos", meaning "downwards". The name resulted from a misunderstanding among the first Spanish missionaries searching for inhabited places along the Calumpit River, these priests came upon some natives of a riverside barrio (now Kanalate). They asked for the name of the place. The natives, not knowing the Spanish tongue, answered that the flow of the river in that part was downstream -"paluslos"-, which the Spaniards pronounced "Malolos". Corruption of the word through the years led to present "Malolos"[4].

The town originated from a small settlement started by the Spanish missionaries. Later, after clearing forests and virgin lands, the settlement grew, and the population increased. After the construction of a big church, the place was made into a town. From the very beginning, Tagalog made up the majority of the Malolos populace. They were led by prominent families, among them the Gatsalians (Gatchalian), and the Manahans [5].

The Malolos Historic Town Center is a historic district located in downtown or old town center of the capital town of Malolos City, Bulacan, Philippines commonly called Camestisuhan or Pariancillo District of Malolos with its collection of Spanish and American-era houses and government structures, as well as being the birthplace of the First Philippine Republic, the Malolos Constitution and being the capital of the Philippines from 1898 to 1900, the National Historical Institute declared the downtown Malolos city as a National Historical Landmark and a Heritage Town dated August 15, 2001.

Kamestizuhan District of Malolos was originally called Pariancillo. It is the district intended for the Chinese residents of Malolos in 1700s. It is all started in 1755 when Governor General ordered the expulsion of chinese from the Philippines due to their participation in some rebellion and sedition against the Spanish Government. Some of them were transferred to Malolos at the time which was already a hub for some chinese and in able to be far from Spanish Government in Manila. When hearing about the migration, Governor General orders that the towns outside Manila should have a special district for them, thus the Malolos Pariancillo was established Pariancillo means "small parian". Upon the order there are provision for those chinese who resides in the town for the longest time that they will not be expelled if they married a native of Malolos and so the Sangleys of Malolos were born and the Pariancillo became the Chinese enclave in Bulacan Province [6].

\subsection{Statement of the Problem}

Cultural mapping and inventory are an ongoing process. And many of its benefits can only be achieved through sustained efforts to update the cultural data and to compare it over time. Because of this, a need to comprehensively consolidate local culture profile and generate baseline data for cultural statistics of Malolos since it was Declared Heritage District in 2001.

\section{Objectives of the Study}

- To appreciate the value of the various cultural resources of the community; 
- To engage with the stakeholders on the process of data gathering and needs analysis. These stakeholders, which include the property owners, residents, caretakers, vendors, the youth sector, the barangay and city governments and the civil societies, have a crucial role in the advocacy cited above and are therefore important to be consulted and asked;

- To consolidate local culture profile and generate baseline data for cultural statistics;

- To recommend mechanisms to integrate profiles and baseline statistics in LGU development plans, programs, and activities.

\subsection{Scope of the Study}

The study will cover the existing condition of Malolos Heritage District, its built heritage environment particularly the existing physical condition of its tangible and intangible cultures that will significantly contribute in the endeavor of this study. The study will also cover festivals and events celebrated annually impacting to the historical and economic condition of the place.

\section{Conceptual Framework}

In the conduct of this study, the researchers followed this paradigm:

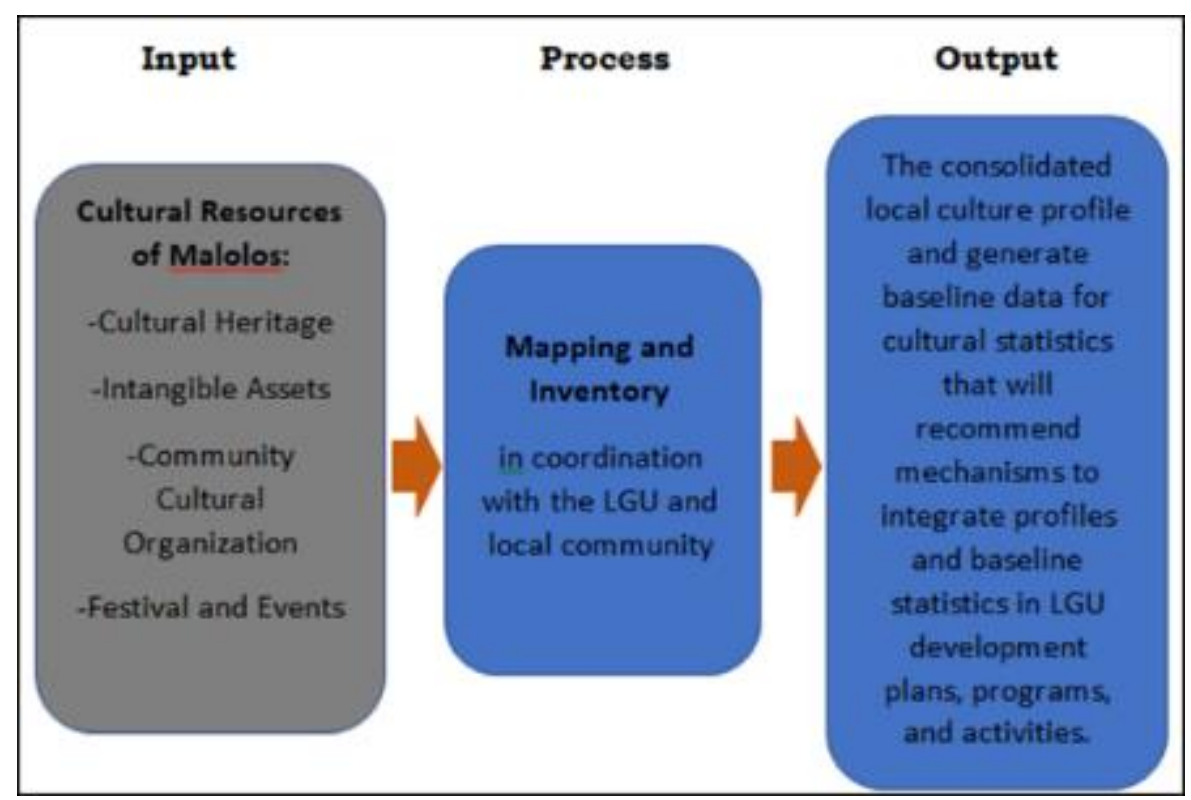

Figure 1 Conceptual Framework

Four of the Cultural Resources in Malolos Heritage District were used as Input, such as -Cultural Heritage, Intangible Assets, Community Cultural Organization, Festival and Events which were subjected for the conduct of Mapping and Inventory activities as the objective of the study.

After gathering the data of the Malolos Heritage District Cultural Resources it was consolidated and the cultural profile were generated as baseline data for cultural statistics that will recommend mechanisms to integrate profiles and baseline statistics in LGU development plans, programs, and activities.

\section{Research Methodology}

The researchers utilized the quantitative and qualitative methods in order to complete the study. This research method will record, describe and analyze data. Mapping and inventory were used to be able to gather necessary data that can only be achieved through the conduct of mapping and inventory of all significant structures relevant to the study.

To pursue the objective, the researcher will conduct cultural documentation procedures. Archival resources will be reviewed to establish the historical context. Pertinent documents will be gathered and reviewed from the City Government of Malolos to identify the past and present development in the area. 
Photo-documentation were used in order to assess the current physical conditions of the heritage structures within the area of Malolos. Pictures will be captured from the outside into the inside of the selected structures. Each picture will be labelled properly. Data analysis of the commonality of details of the architectural structures through comparative approach will be done to isolate the factors of the significant and the common details and features of the significance architectural edifice.

Mapping and inventory were used to be able to gather necessary data that can only be achieved through the conduct of mapping and inventory of all significant structures relevant to the study.

\subsection{SWOT analysis of Kamestizuhan Heritage District}

The analyses of present condition and implications of the preservation of cultural heritage site zone and its environment were merged as to identify the strengths, weaknesses, opportunities and threats, and connect their relationships for possible strategies to be integrated in the proposal.

The determinants of this analysis are focused on: the location and land use which are essential in considering the accessibility and level of awareness of the users towards the Kamestizuhan Heritage District, as well as how the possible development will function, despite having conflict between the general zoning as utility, and the actual land use as mixed-use; streetscapes that will determine the quality of site development planning based on the character and visual accessibility of the users; location, land use, existing structures, road networks/ parking space, utilities and vegetation of the site that are important to factors in the analysis of the site in an urban area; specifically in Pariancillo Street, Sto. Nino Street, F.T. Reyes Street, Zulueta Street and Estrella Street.

The corresponding strategies for the site involve on the relation of heritage structures and arising development, preservation of its natural environment and revitalization of streetscapes, and consideration for the circulation and security of the physical elements and the users.

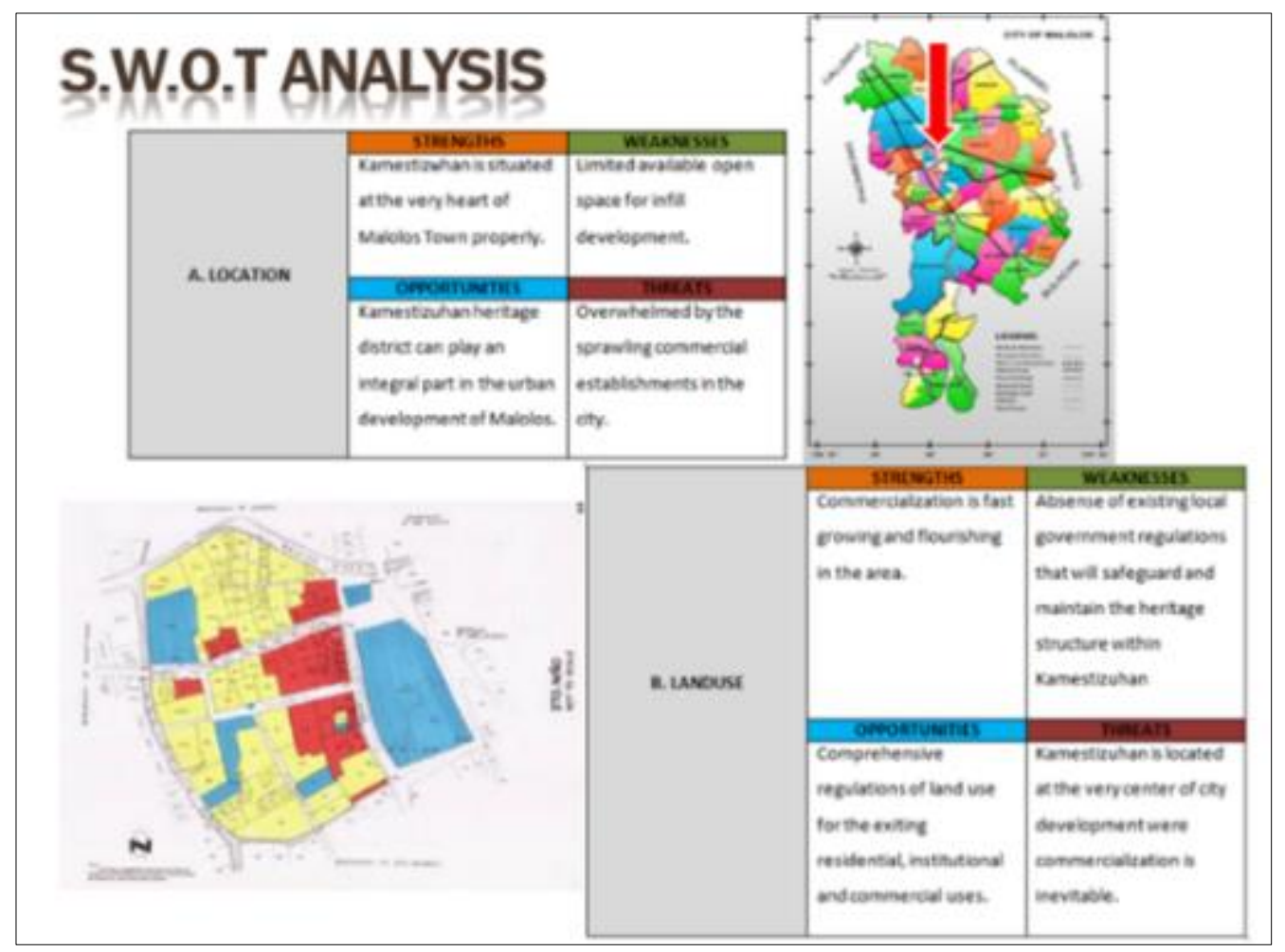

Figure 2 SWOT Analysis 


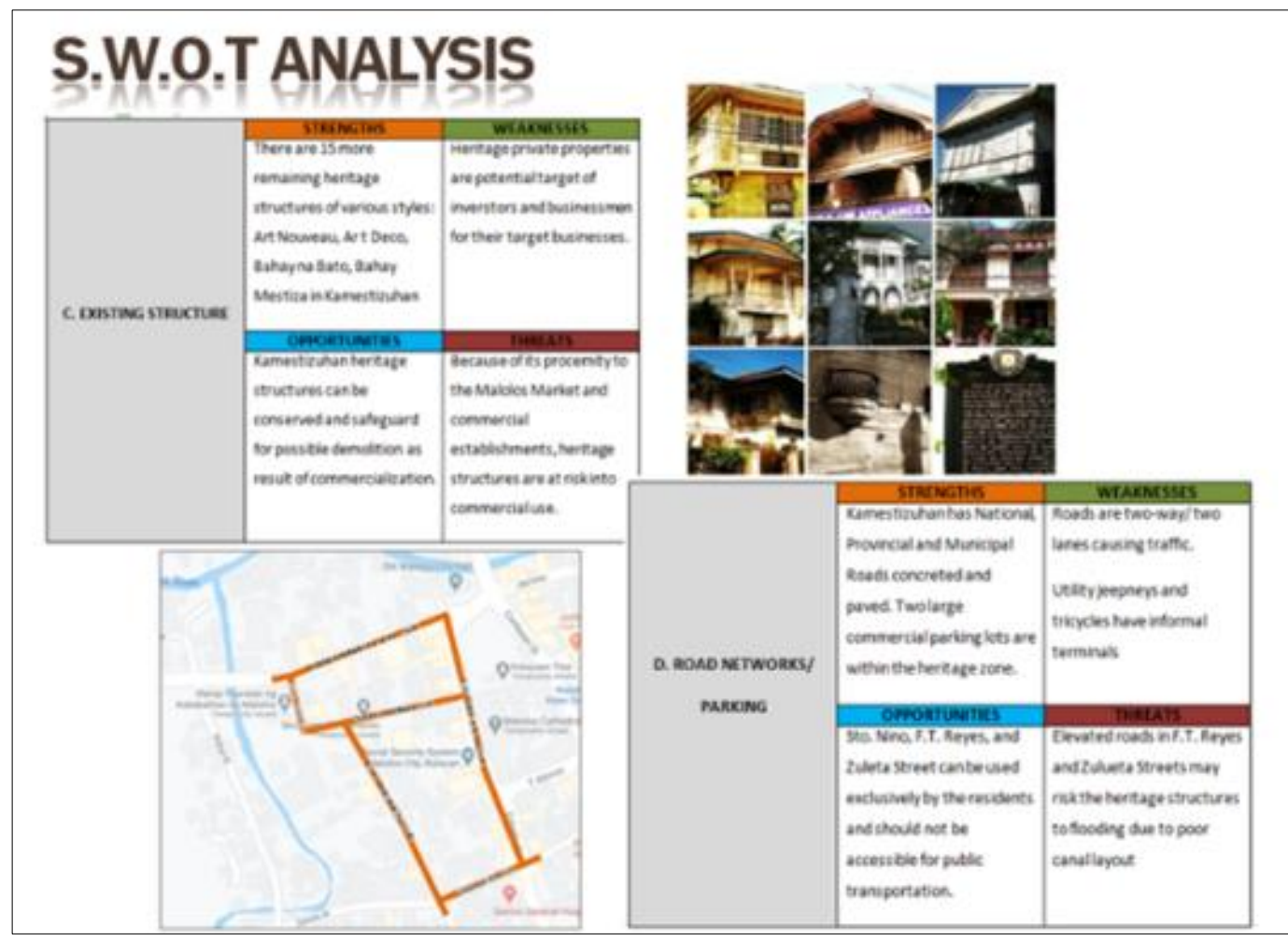

Figure 3 SWOT Analysis

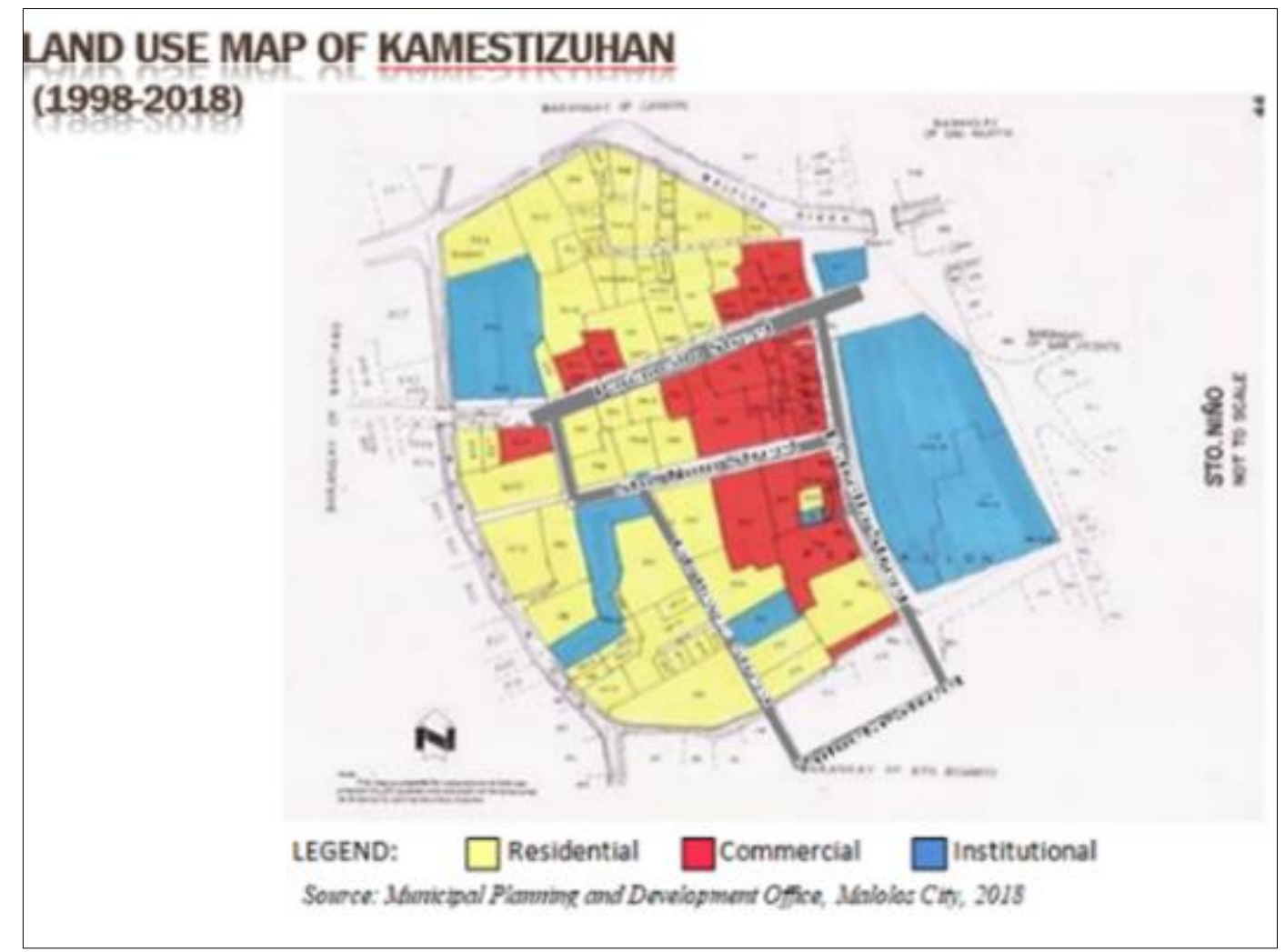

Figure 4 Land Use Map of Kamestizuhan 


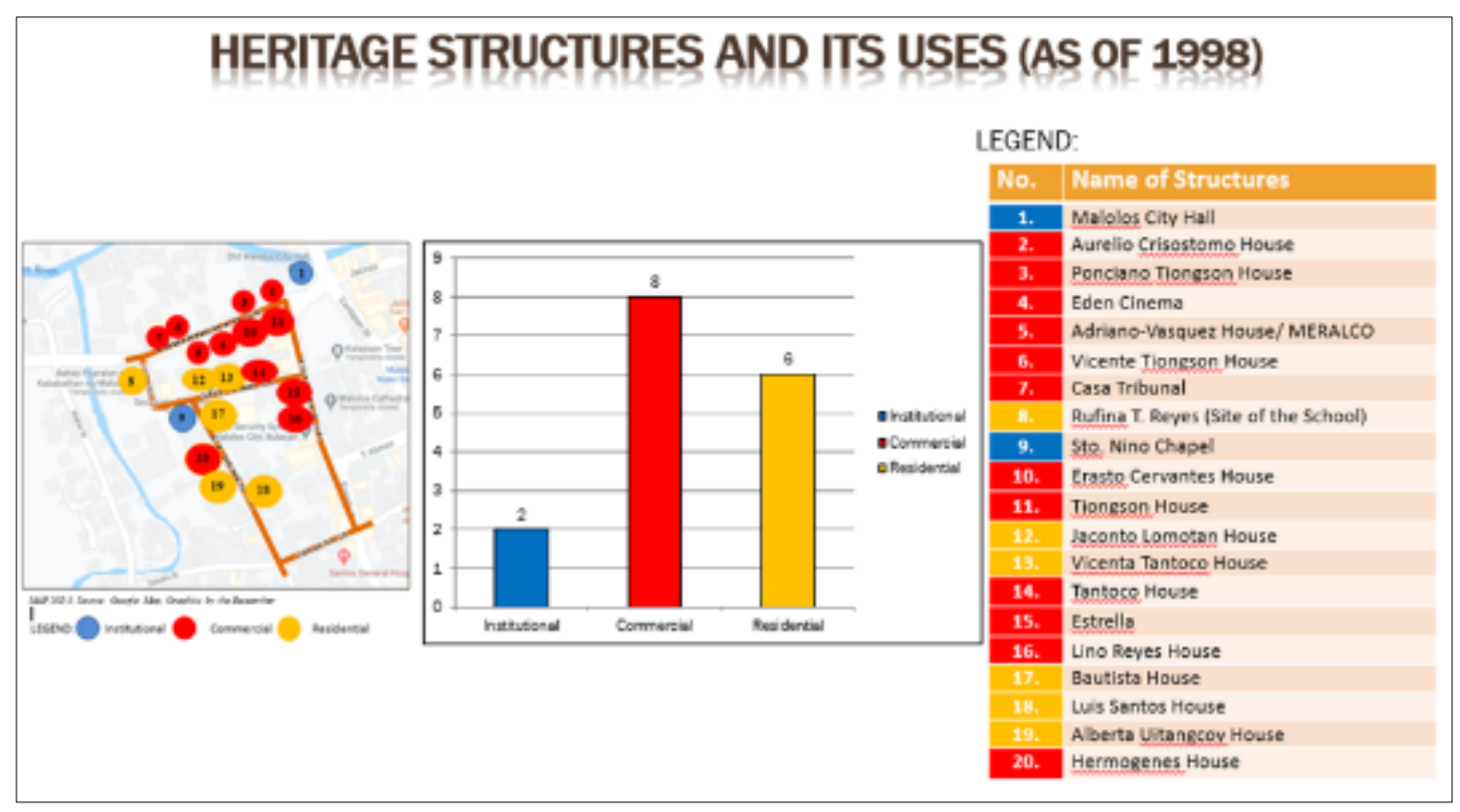

Figure 5 Heritage Structures Mapping and Inventory

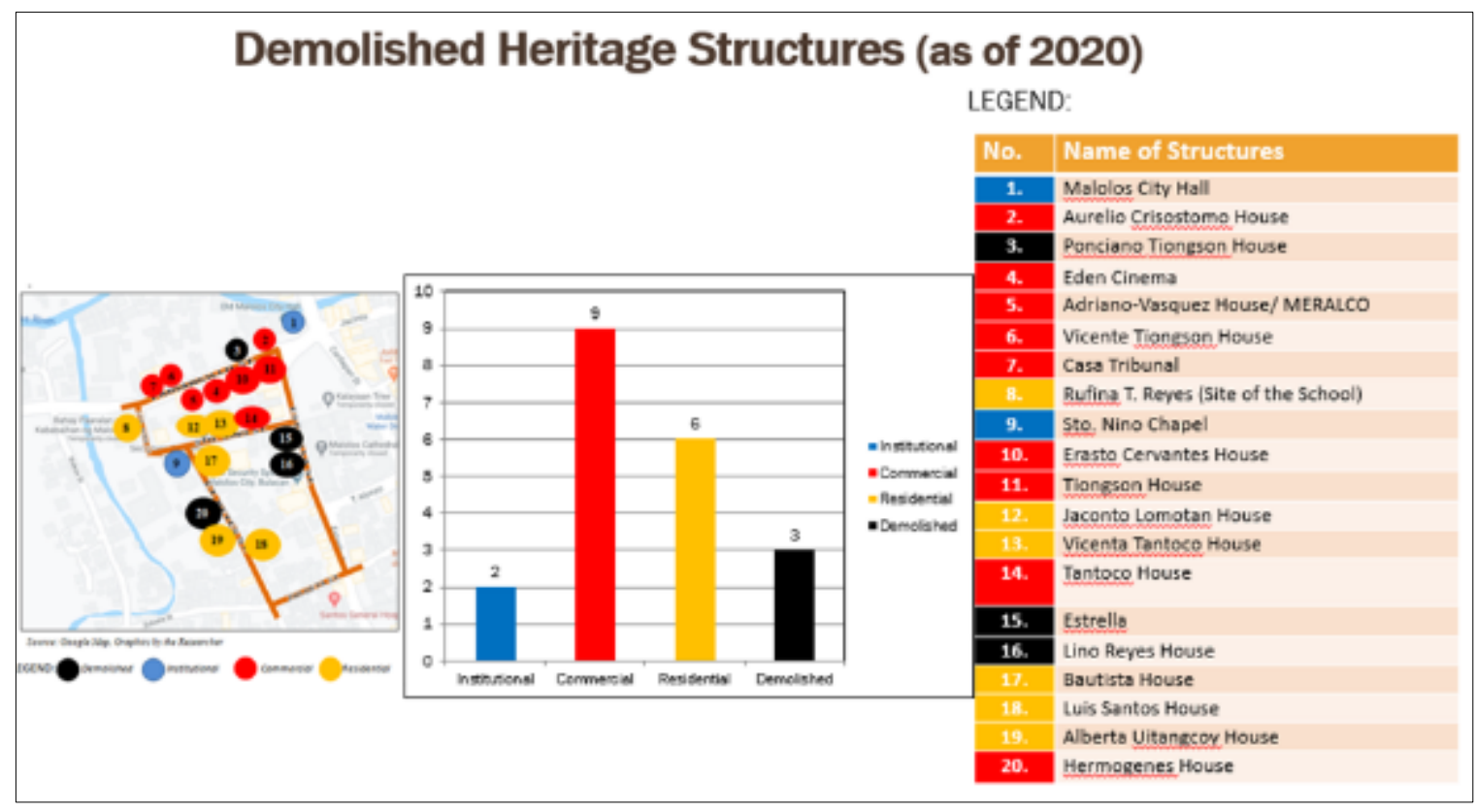

Figure 6 Heritage Structures Mapping and Inventory 


\section{Inventory of commercial establishments in every Ancestral House (as of 2020)}
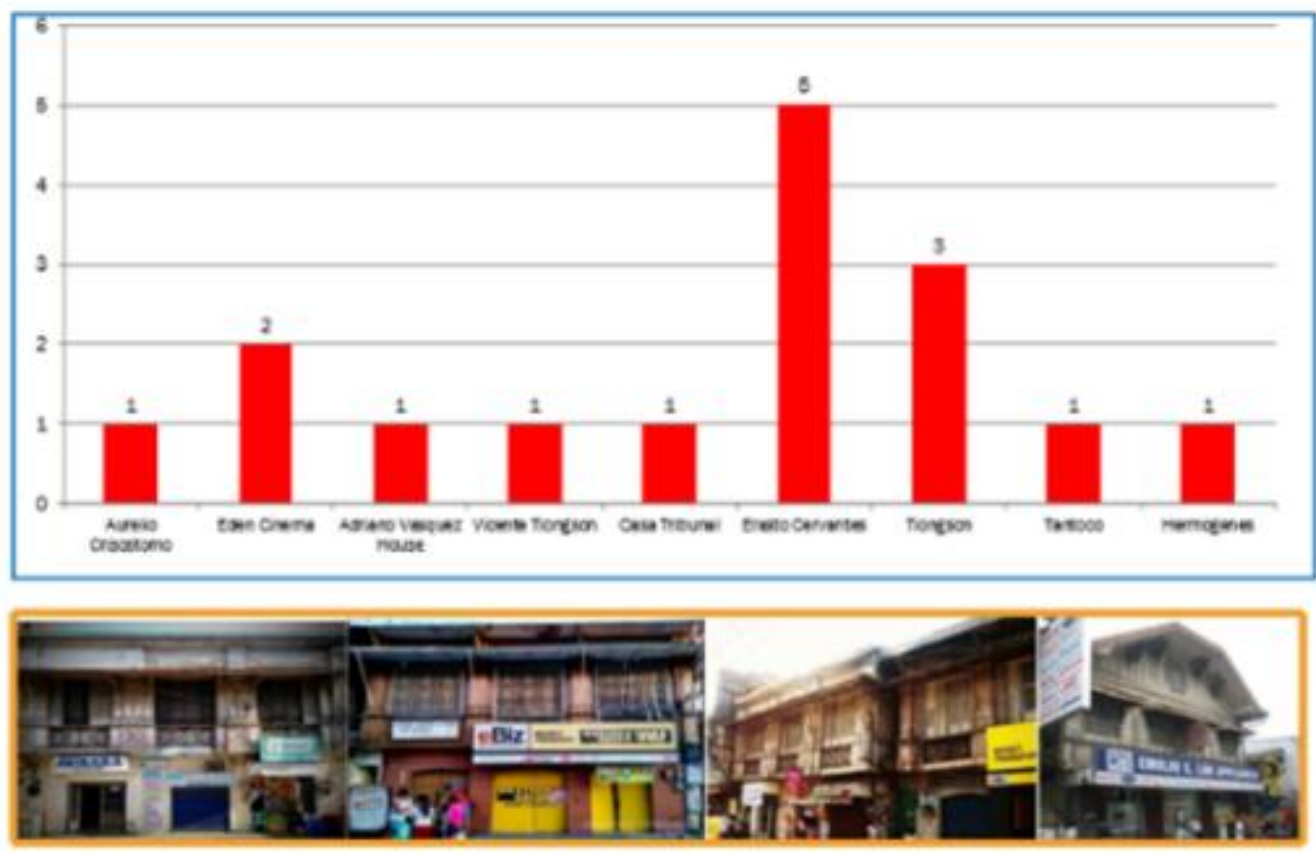

Figure 7 Inventory of Commercial Establishments

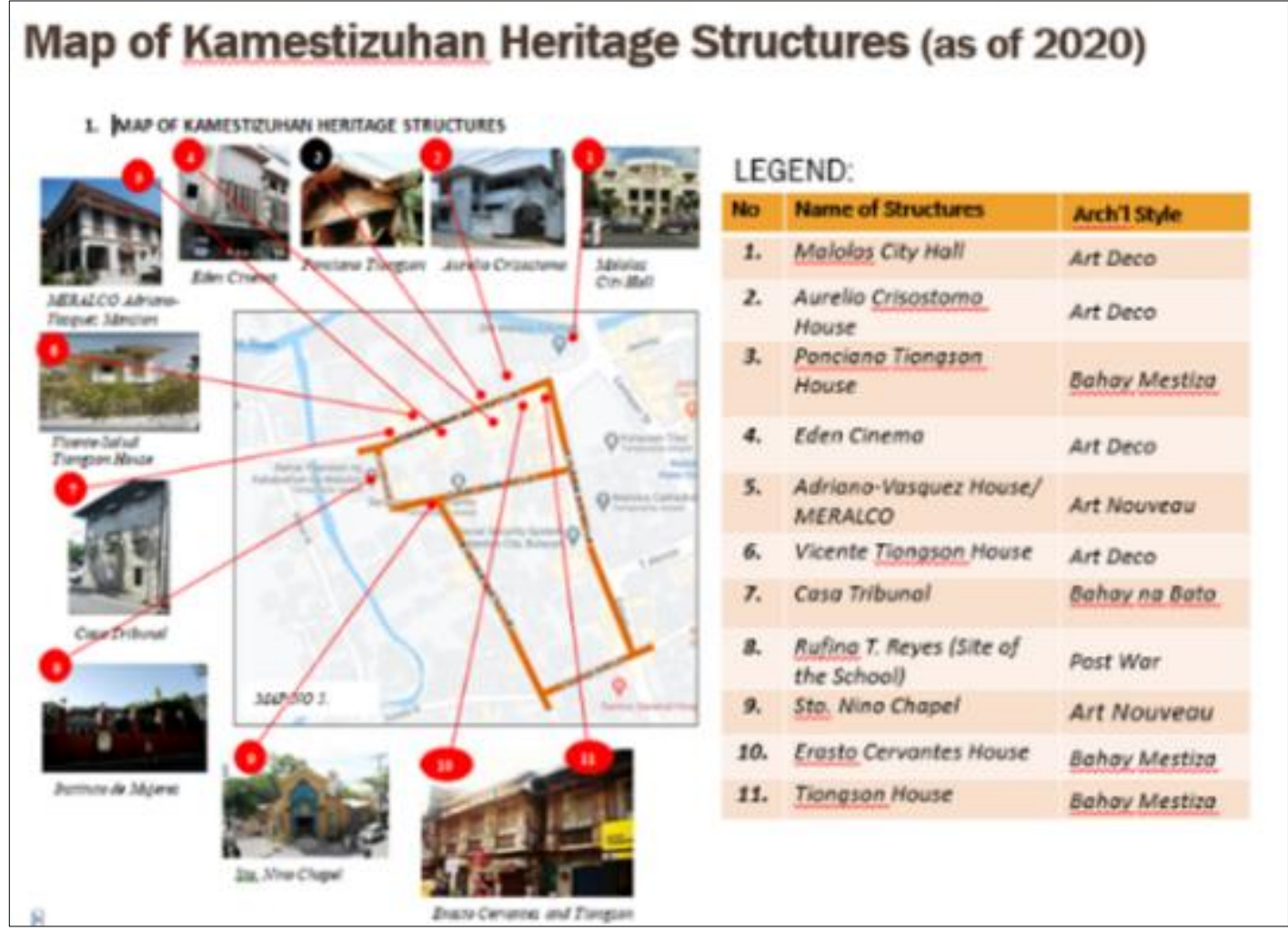

Figure 8 Mapping and Inventory of Heritage Structures 


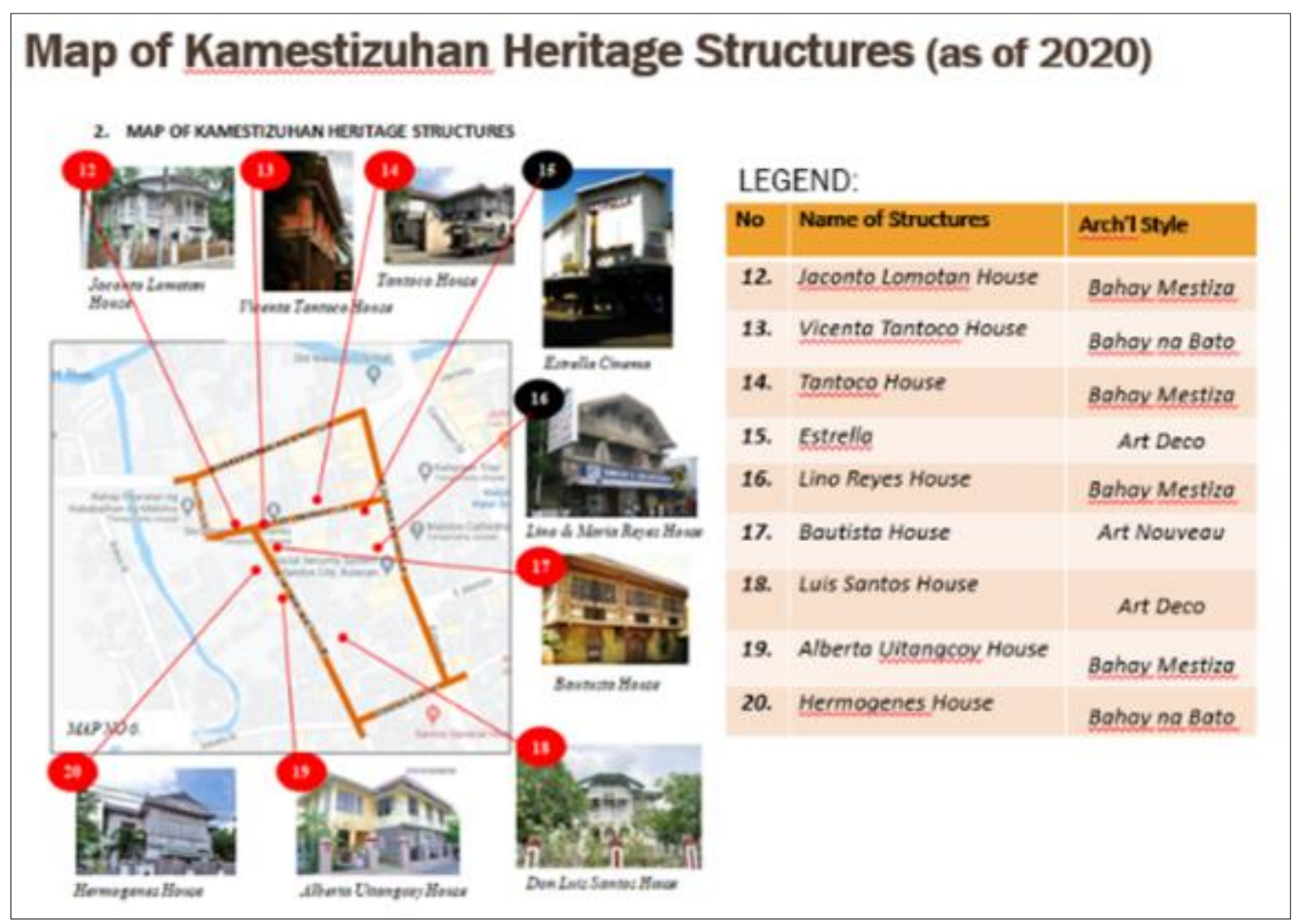

Figure 9 Mapping and Inventory of Heritage Structures

\section{INVENTORY AND PHOTO DOCUMENTATION}

The following data are inventory of the Twenty Heritage Structures in Kamestizuhan Heritage District. Each Structure has corresponding basic information like owner's name. current use and Assessment of Sginificance using the legend at the upper right. Also, a brief information about the the structure's historical

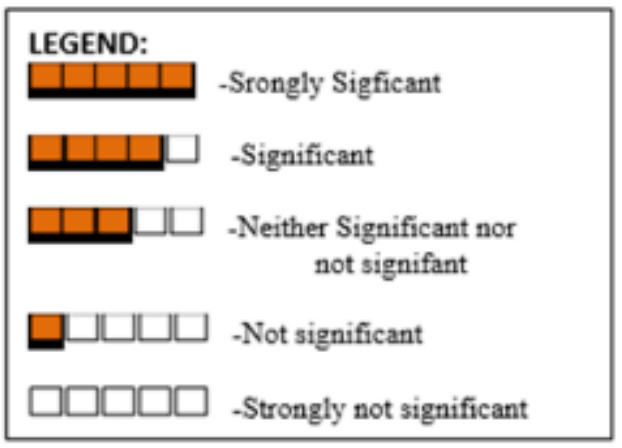
and architectural significance are presented.

Figure 10 The rating scale used for the inventory on the level of significance 


\section{Significance priority ratings}

\begin{tabular}{|c|c|c|}
\hline Rating & Description & Condition \\
\hline $\begin{array}{c}1- \\
\text { square }\end{array}$ & $\begin{array}{l}\text { The level of significance (historical/ aesthetic/ } \\
\text { social/ economic) is highly exceptional, almost } \\
\text { perpect. }\end{array}$ & $\begin{array}{l}\text { Strongly } \\
\text { Significant }\end{array}$ \\
\hline $\begin{array}{c}2- \\
\text { squares }\end{array}$ & $\begin{array}{l}\text { The level of significance (historical/ aesthetic/ } \\
\text { social/economic) is high. }\end{array}$ & Significant \\
\hline $\begin{array}{c}\text { 3- } \\
\text { squares }\end{array}$ & $\begin{array}{l}\text { The level of significance (historical/ aesthetic/ } \\
\text { social/ economic) lacks some aspect but does } \\
\text { affect to the totality. }\end{array}$ & $\begin{array}{l}\text { Neither } \\
\text { Significant nor } \\
\text { not } \\
\text { significnant }\end{array}$ \\
\hline $\begin{array}{c}\text { 4- } \\
\text { squares }\end{array}$ & $\begin{array}{l}\text { The level of significance (historical/ aesthetic/ } \\
\text { social/ economic) lacks more aspect that affect } \\
\text { to the totality. }\end{array}$ & Not significant \\
\hline $\begin{array}{l}5- \\
\text { squares }\end{array}$ & $\begin{array}{l}\text { The level of significance (historical/ aesthetic/ } \\
\text { social/ economic) lacks all aspect that affect to } \\
\text { the totality. }\end{array}$ & $\begin{array}{l}\text { Strongly not } \\
\text { significant }\end{array}$ \\
\hline
\end{tabular}

Table 1 Guide for rating the significance level of the structures

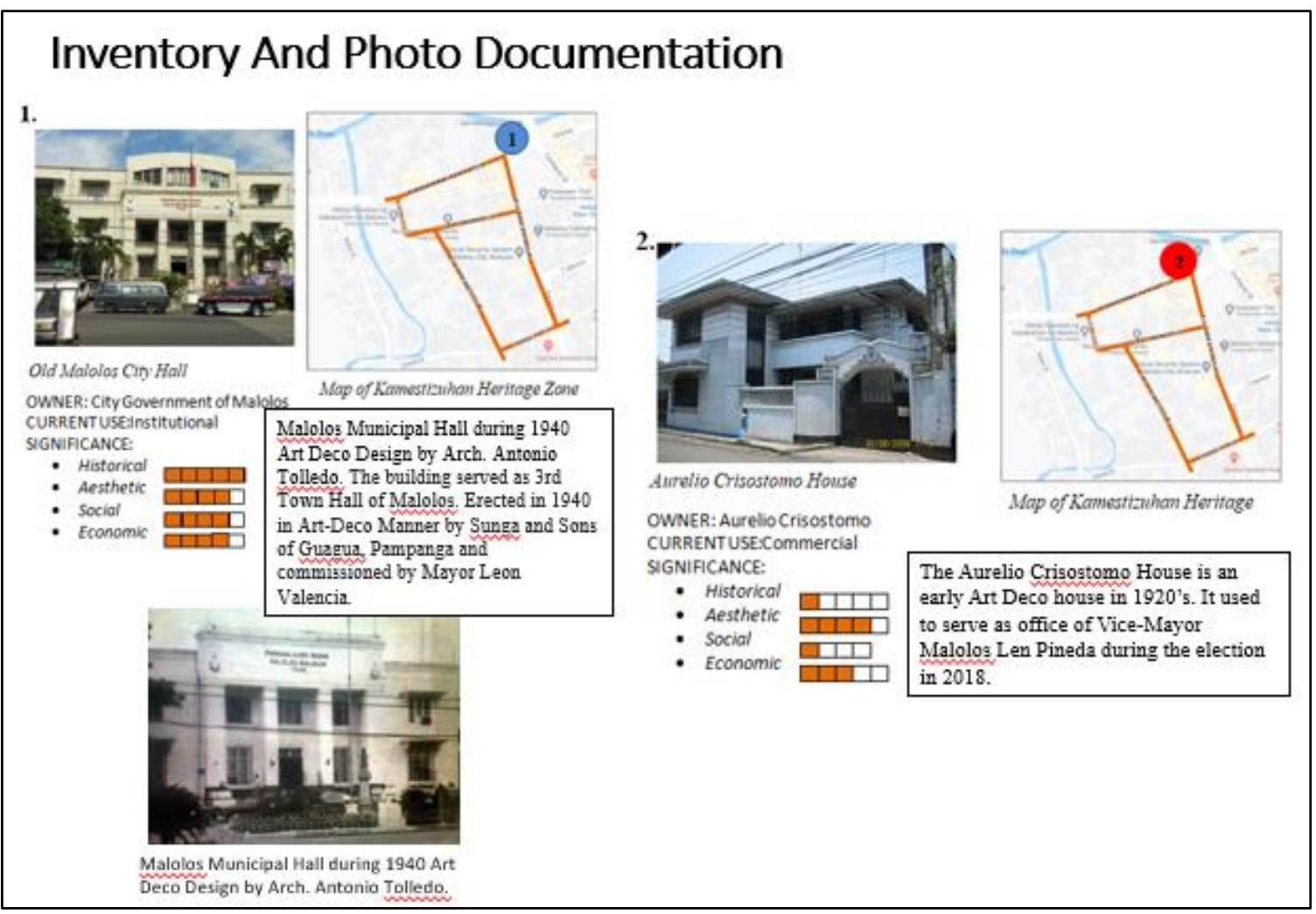

Figure 11 The Town Hall Building and Crisostomo House 


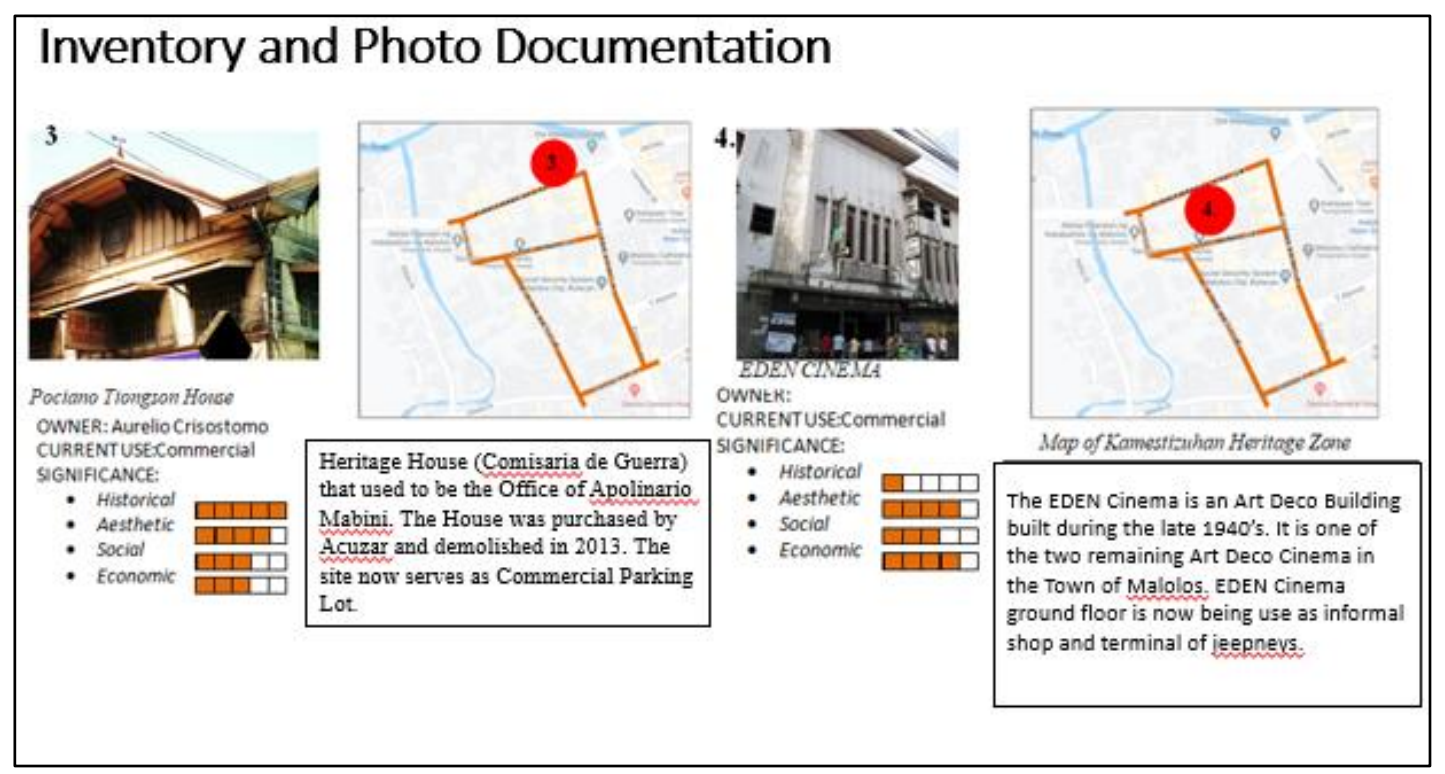

Figure 12 The Tiongson House and Eden Cinema

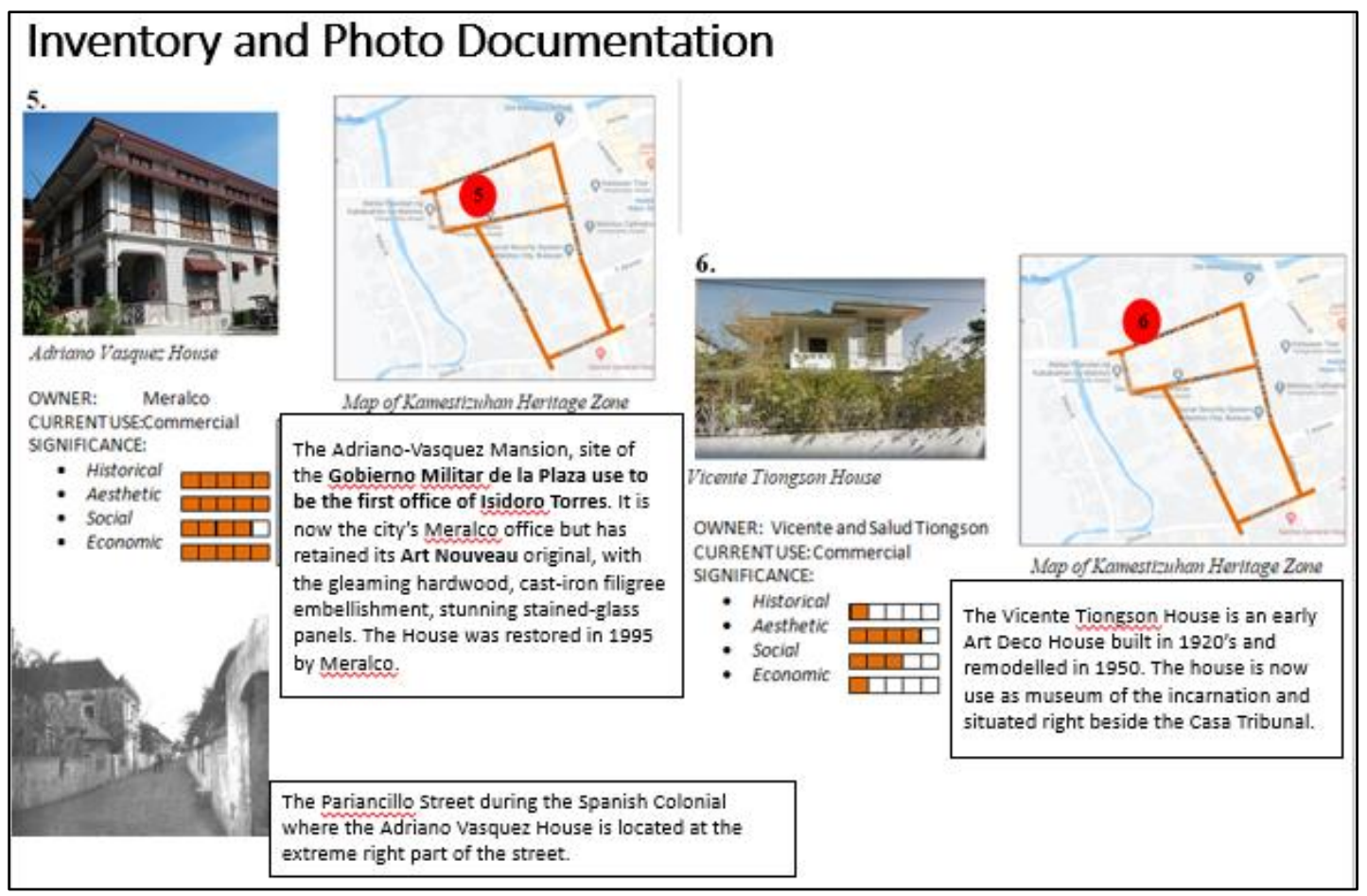

Figure 13 The Vasquez House, Pariancillo Street and Tiongson House 


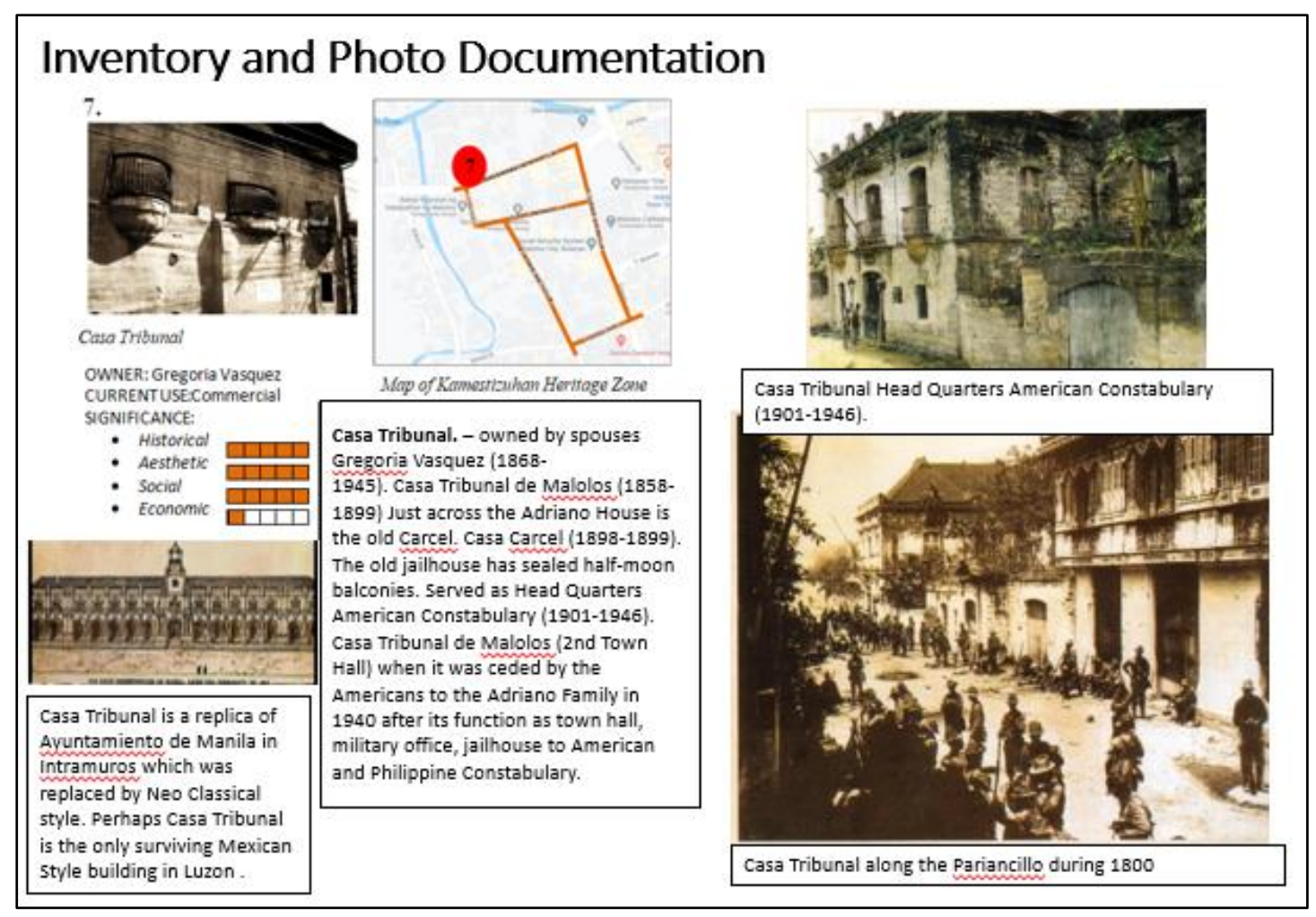

Figure 14 The Casa Tribunal

\section{Inventory and Photo Documentation}

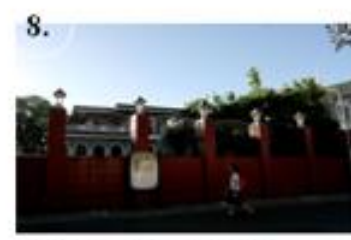

SITE: Institito de Mugeres

OWNER:

CURRENTUSE:Residential

SIGNIFICANCE:

- Historical

- Aesthetic

- Sacial

- Economic

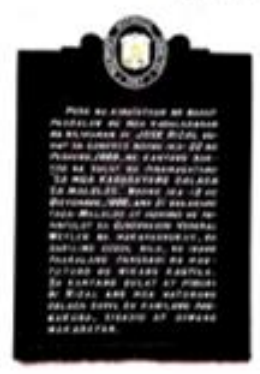

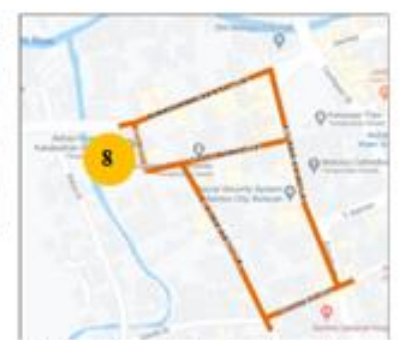

Map of Kamestizuhan Heritage Zone

INSTITUTO DE MUJERES. Turning left at the next corner is the Reyes House, the site where Jose Rizal's Letter To the Women of Malolos was read. It was through this letter that Rizal (writing from Spain) gave

encouragement to the brave women who established a night school for women, the Instituto de Mujeres, against the objections of the town friars.

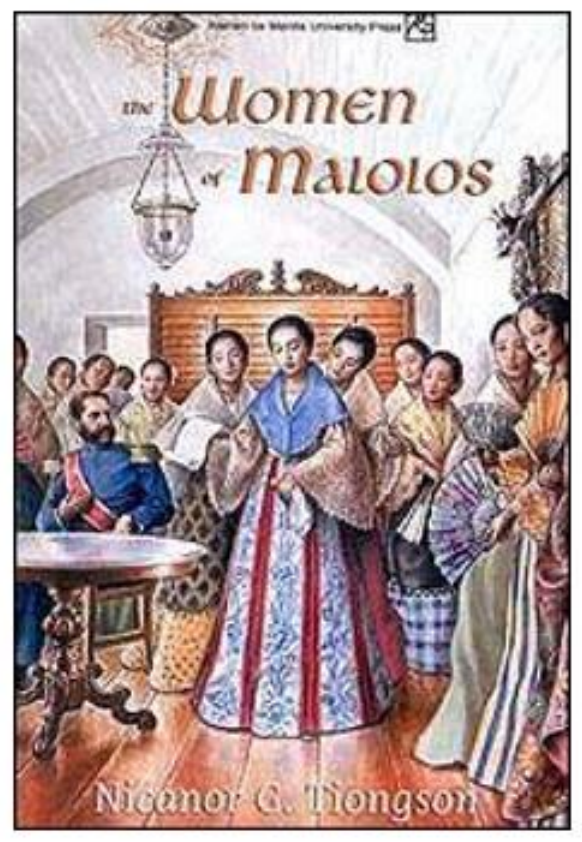

Figure 15 The Instituto de Mujeres 


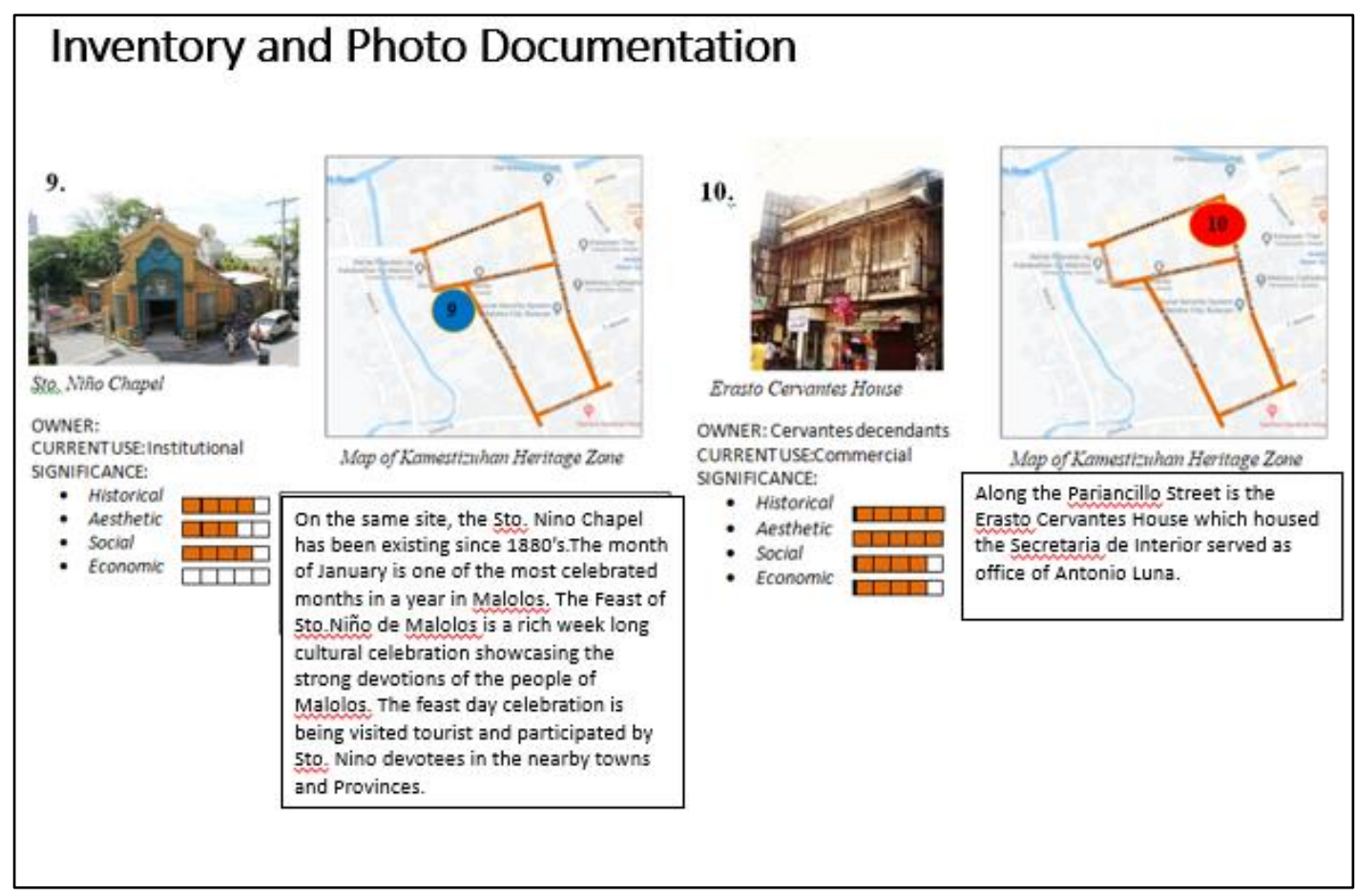

Figure 16 The Santo Niño Chapel and Erasto Cervantes House

\section{Inventory and Photo Documentation}

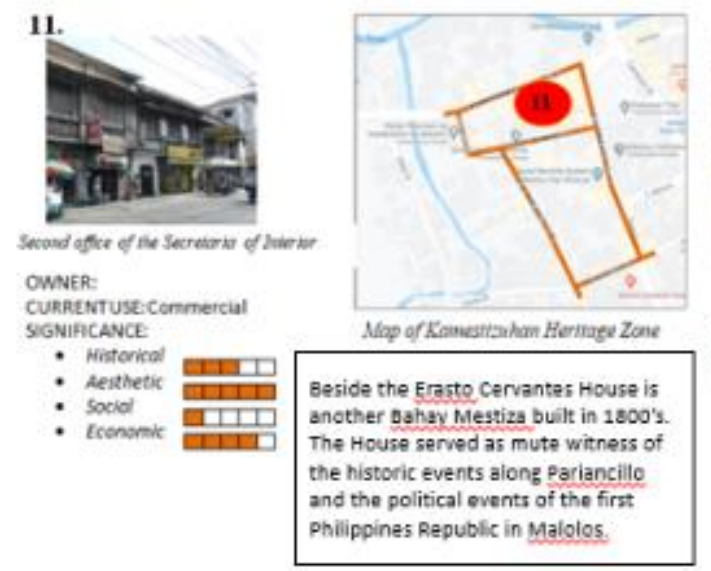

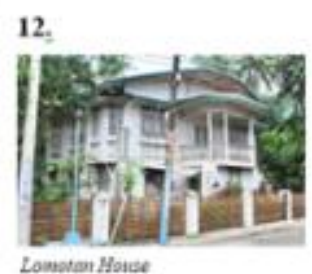

Lowoten House

OWNER: Lemotan greatgand children CURRENTUSER ESISEntial

SIGNIACANCE:

- Mesthetic

- Socipl

- Lconomic

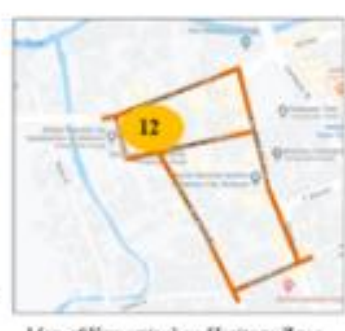

Map of Kimeaniawhan Reringe Zone

o Lomotan House is a 1930 Art Deco House across the instituto de Meiures, use to be the descendant of one of the 21 Women of Malolos.

Figure 17 The Cervantes House and Lomotan House 


\section{Inventory and Photo Documentation}

13.

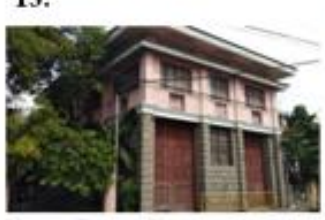

Vicenta Tautoco Hoice

OWNER: Oscar Reyes/Lydia Echauz CURRENTUSE: Residential SIGNIFICANCE:

- Historical

- Aesthetic

- Socio Economic 매밀

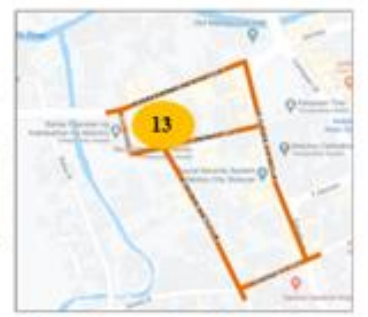

Map of Xamestizuhan Heritage Zane The Vicente Tantoco House was restored in 2013 after it was acquired by Oscar Reyes and Lydia Echauz. President of MERALCO, the street in front known today as the F.T. Reyes St. Used to be calle Electricidad during the Spanish Era.

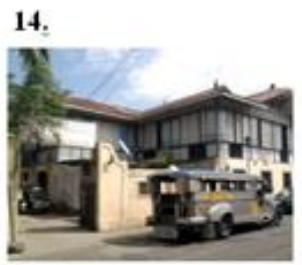

Teresa \& Maria Tantoco Honse OWNER: Tantoco heirs CURRENTUSE:Barangay Hall/Day Care Map of Kamesticuhan Hertage Zone SIGNIFICANCE:

- Historical Teresa and Maria Tantoco are siblings

- Aesthetic

- Social and members of the Women of Malolos. The house is a Bahay na Bato built in 1880 's. At present, it is being use as Sto. Niño Barangay Hall, MultiPurpose Hall, and Day Care Center.

Figure 18 The Tantoco Houses

\section{Inventory and Photo Documentation}

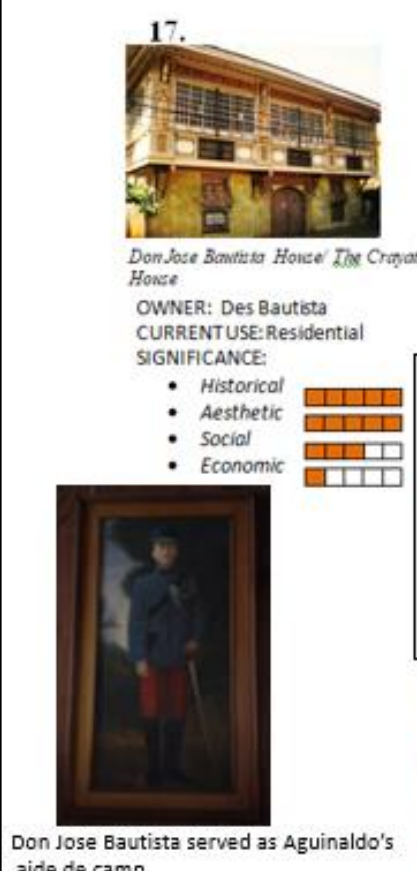

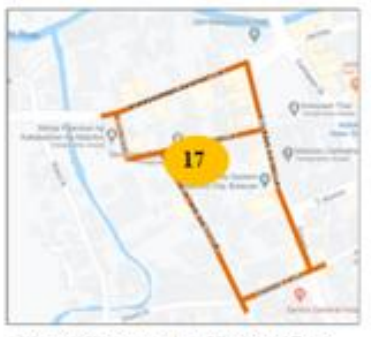

Map of Kamestizuhan Heritage Zone The Baustista House, Don Jose Bautista served as Aguinaldo's aide de camp. The house served as office of the secretaria de Fomento. House was built before the 18505 and was remodeled in 1877 with the addition of caryatids, resulting in a happy blend of the Neoclassic style and French Art Nouveau. It is probably the only house in the country with caryatids on its façade.

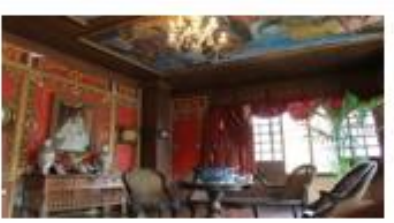

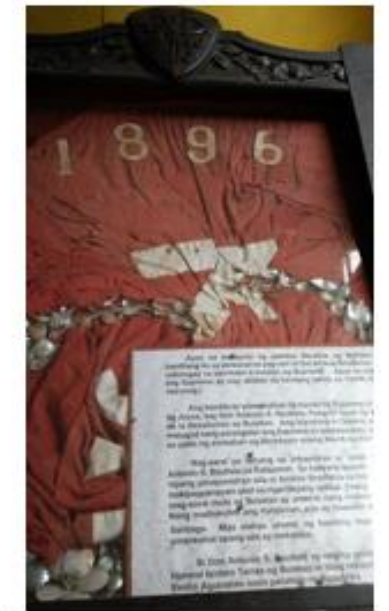

Inside the Baustista House, according to Mr. Basildez Bautista, above is the personal flag of Andres Bonifacio given to Don Antonio

Bautista by Gregoria de Jesus when the latter was invited to the house.

Figure 19 The Bautista House 


\section{Inventory and Photo Documentation}

15.

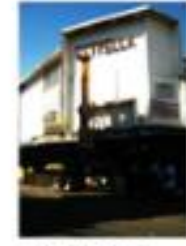

Dowlit Conent

OWNer: Mc Denald:

CURRENTUSE:Commercialaidy SGNIACANCE:

- Natorical

: Aesthet:

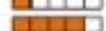

- Economi 밈

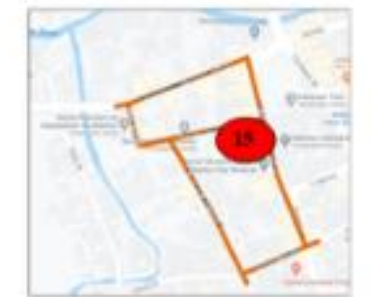

Mop of Kaneatiahon Hertiage Zane

Eatrella Cinema is an Art Deco

Structure that was demolished in

2015 for the construction of Throe

Storey Commercial Building of Mc Donald.

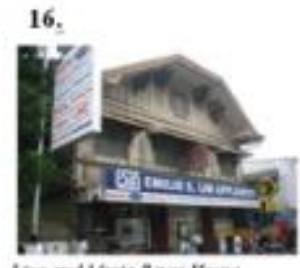

Lino and Maria Reves Howse OWNex: Reves Deceedant CURRENT USE Commescialpariang. GNIFACANCE - Historikal

MaBin's OfFice. Across the church

- Socied allong Estrolla Street is the Lino and

- fecenanir 111 Maria Reyes House with its weathered

- fronomir EIII wind vain and octagonal rose windowa.

This house served as the office

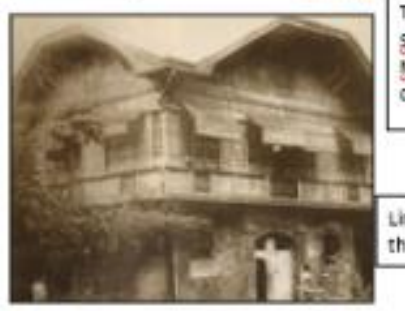

Secretaria de Exterior of Apolinario Mabini when he was also appointed as chief adviser to President Azuinaldo

tho and Maria Reves House during the Spanish Colonial time.

Figure 20 The Estrella Cinema and the Reyes House

\section{Inventory and Photo Documentation}

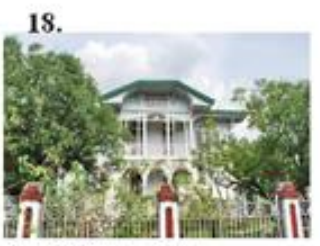

Dr. Luis Soutes. House

OWNER: Dr. Santos (son of Dr. Luis)

CURRENTUSE:Residential SIGNIFICANCE:

- Hesthetic प11त

- Aesthetic पाम

- Economic

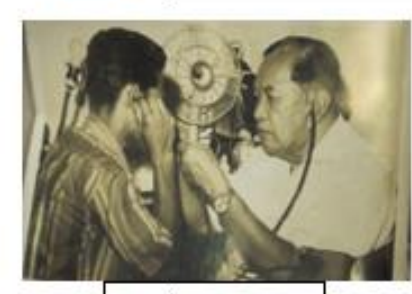

Dr. Luis 5antos of the 5antos.

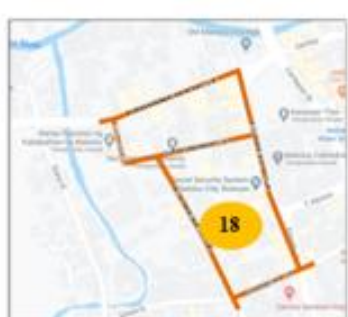

Map of Ramestizuhar Herifage Zone

The Dr. Luis Santos House, built in 1933 designed by Antonio Caudal a furniture designer at that time and a close friend

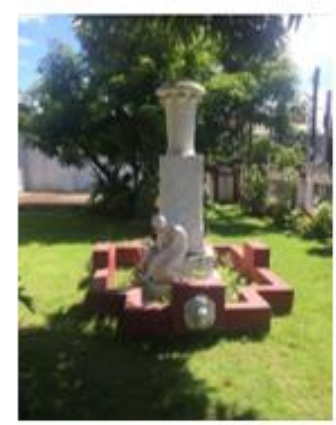

The fountain in Santos House was done by National Artist Guillermo Tolentino.

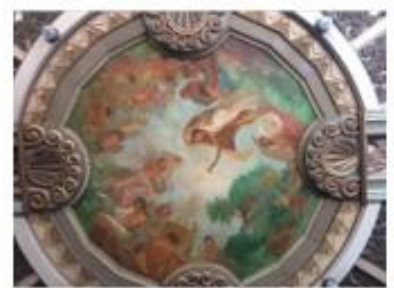

The ceiling of the house was painted by Fernando Amorsolo.

Figure 21 The Luis Santos House 


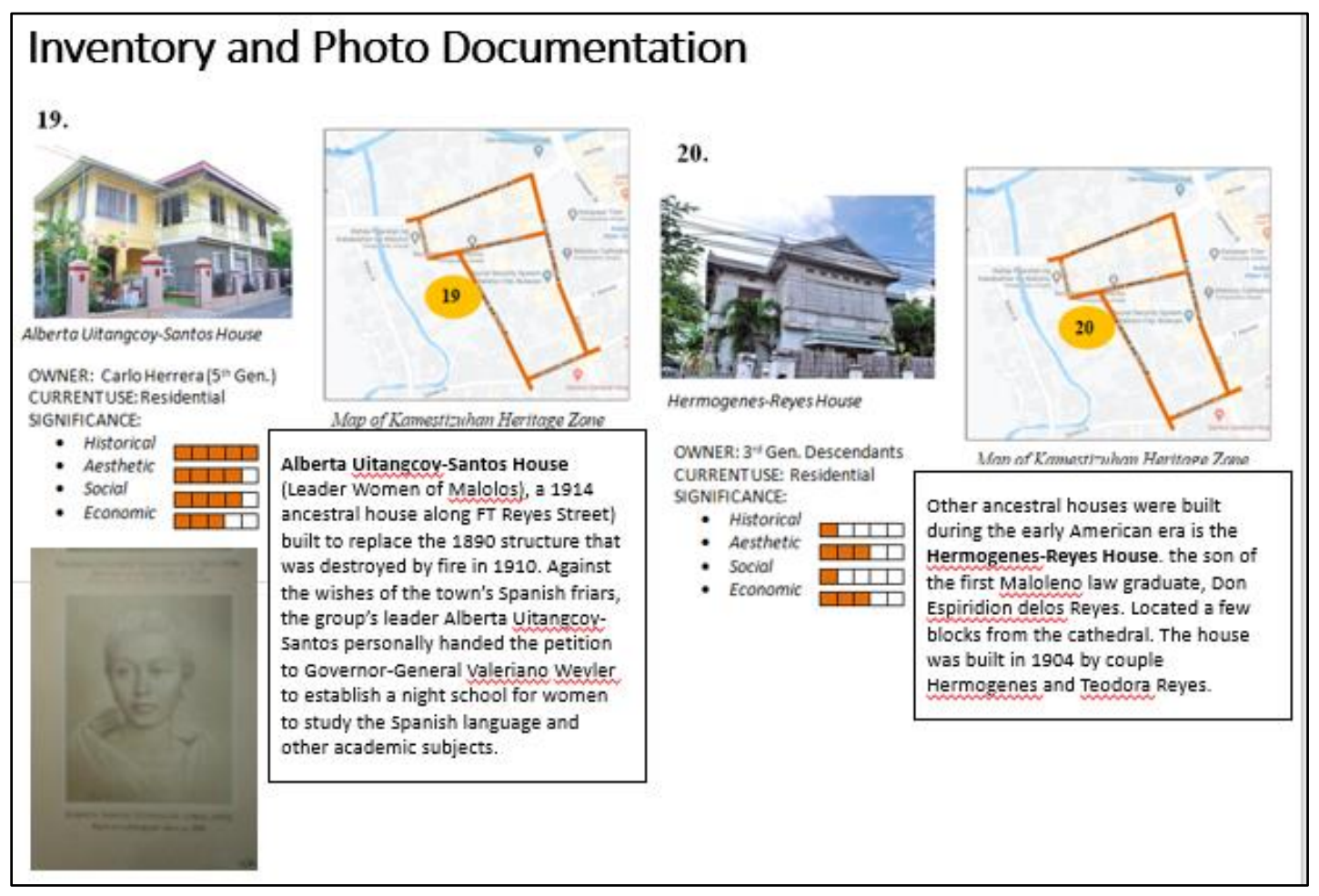

Figure 22 The Uitangcoy House and Hermogenes House

\section{Inventory and Photo Documentation}

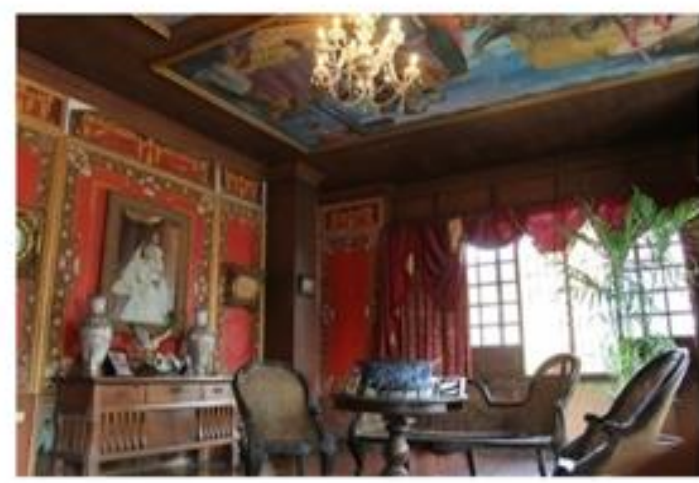

The ceiling in the living area at the second floor of the Bautista House was painted by Luna.

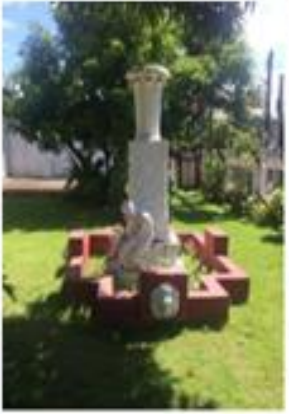

The fountain in Santos House was done by National Artist Guillermo Tolentino

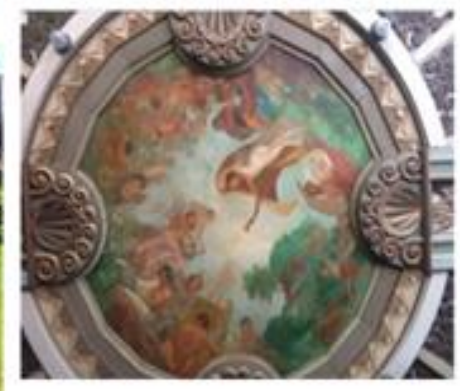

The ceiling in the living area at the second floor was painted by Fernando Amorsole.

Figure 23 The Luna fresco in Baustista House and the Armosolo Fresco in Santos House 


\section{INVENTORY AND PHOTO DOCUMENTATION}

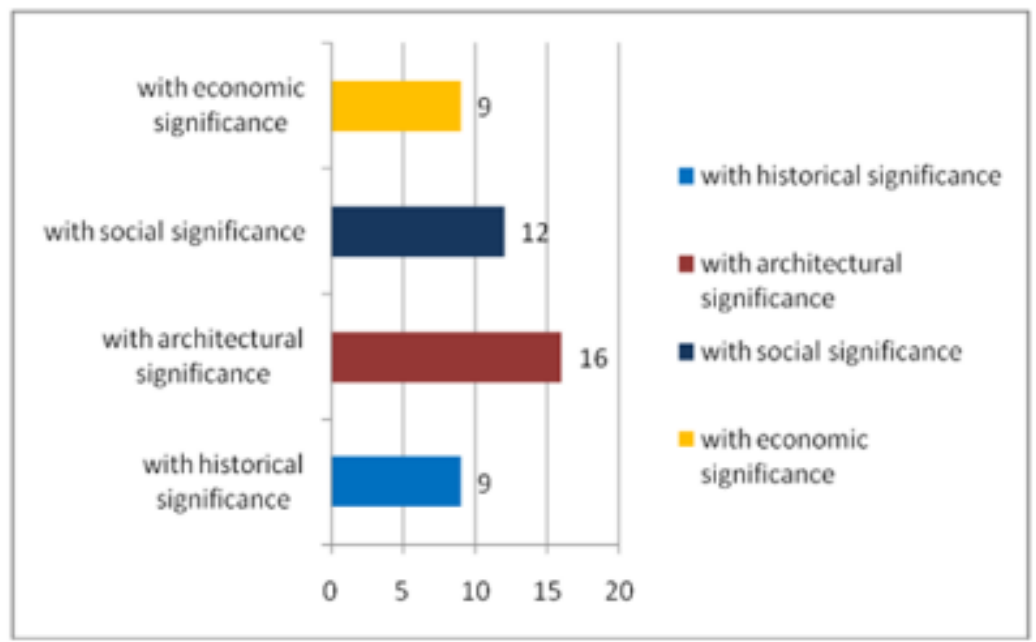

Out of the twenty Heritage Structures in Kamestizuhan District, nine structures has strong historical significance and sixteen has Aesthetic or architectural significance Twelve structures has social significance and nine has economic significance.

Figure 24 The level of significance based on the survey result

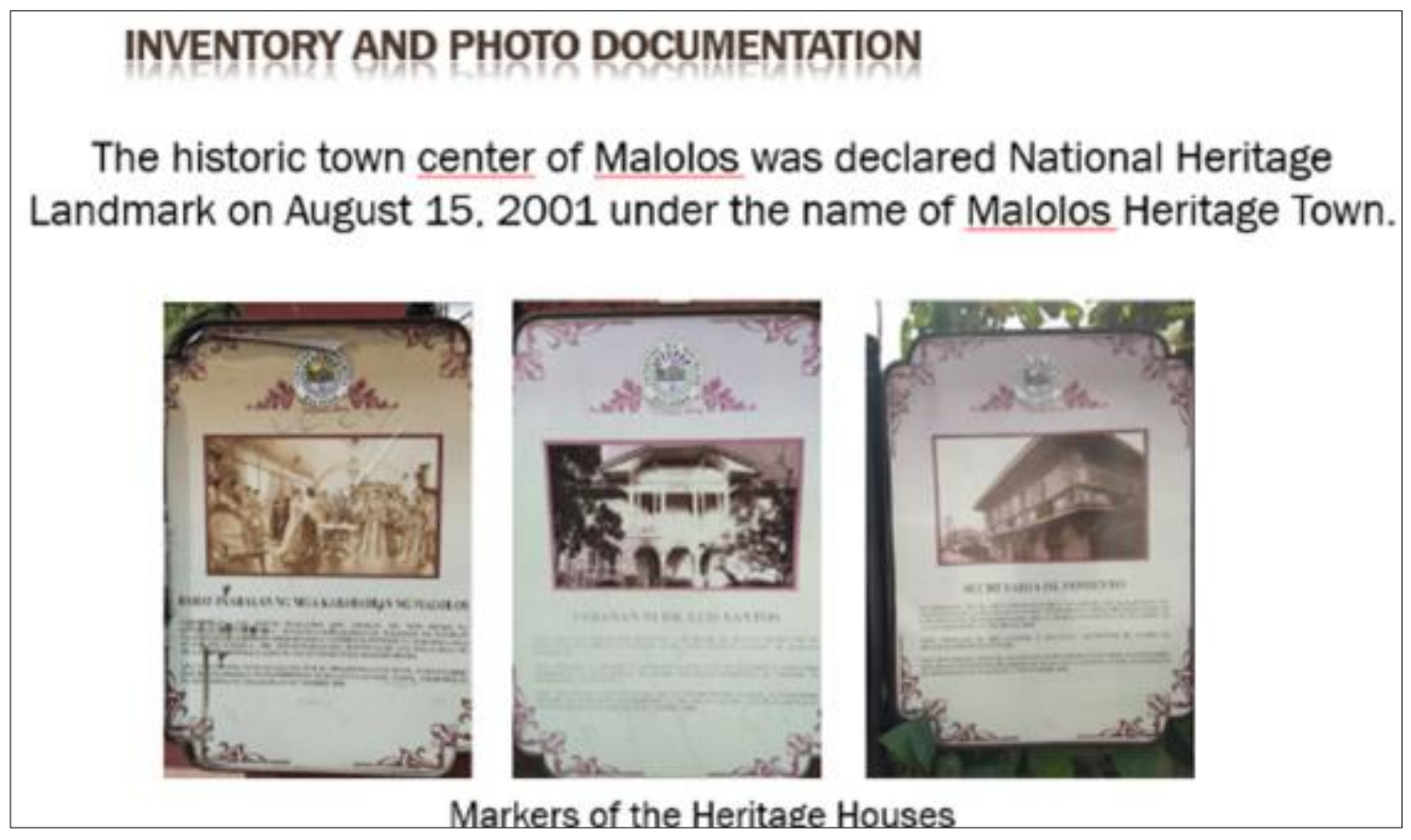

Figure 25 The installed local government markers 


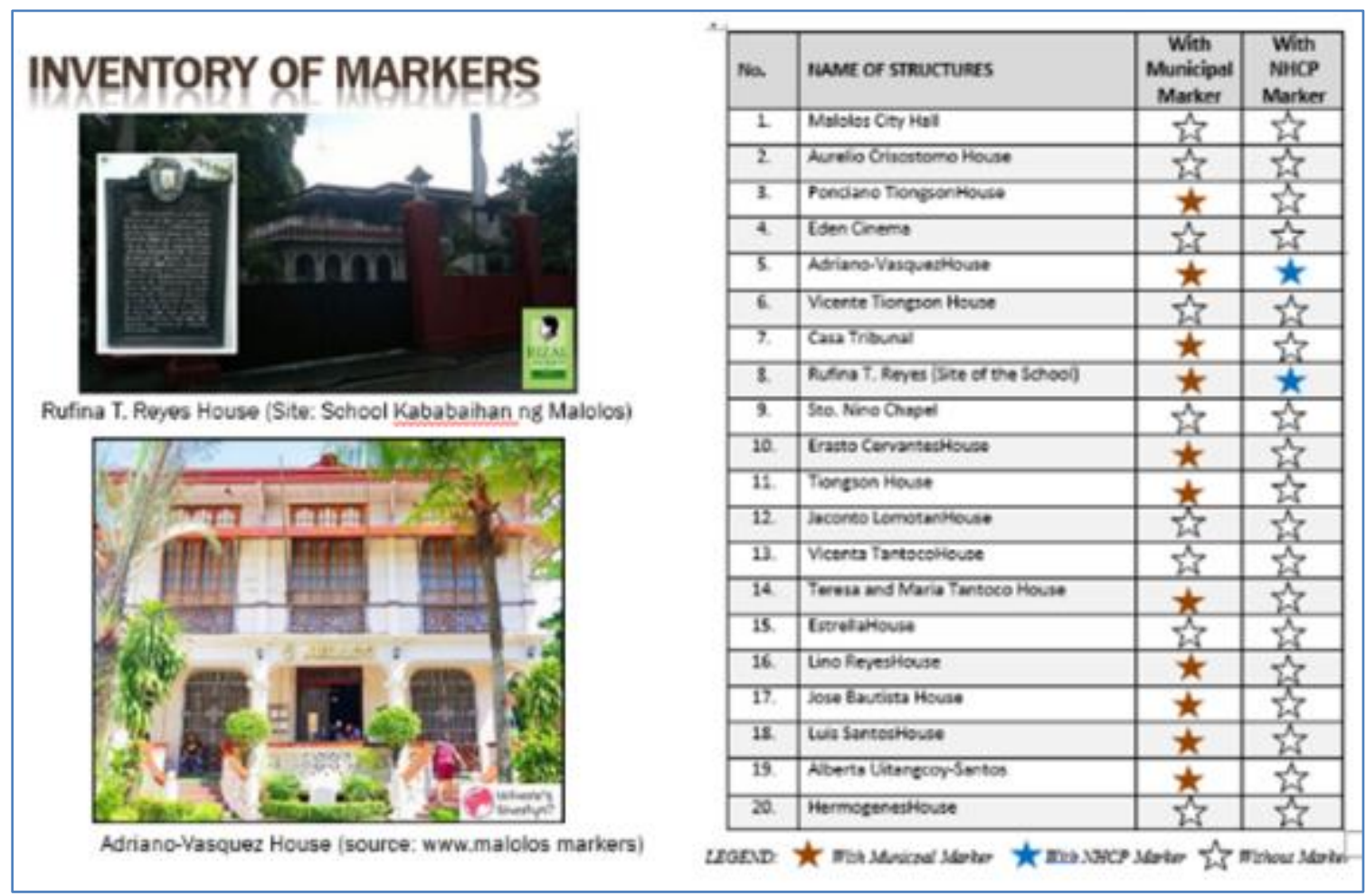

Figure 26 The Inventory of local and NHCP Markers

\section{Inventory of Structures}

\begin{tabular}{|l|l|l|l|l|}
\hline No. & \multicolumn{1}{|c|}{ Name } & \multicolumn{1}{|c|}{ Year } & \multicolumn{1}{|c|}{ Remarks } \\
\hline 1. & Malolos City Hall & Art Deco & 1940 & In fair condition \\
\hline 2. & Aurelio Crisostomo House & Art Deco & 1900 's & In good condition \\
\hline 3. & Ponciano TiongsonHouse & Demolished & No record & Now Paking area \\
\hline 4. & Eden Cinema & Art Deco & 1940 's & Deteriorating \\
\hline 5. & Adriano-VasquezHouse & Bahay Mestiza & 1870 's & Adaptive Reuse/In good condition \\
\hline 6. & Vicente TiongsonHouse & Art Deco & No record & Museum/ In good condition \\
\hline 7. & Casa Tribunal & Bahay na Bato & 1859 & Deteriorating \\
\hline 8. & Instituto de Mujeres & Ruin & 1970 's & Wall Ruins \\
\hline 9. & Sto. Nino Chapel & Renaissance & & In good condition \\
\hline 10. & Erasto CervantesHouse & Bahay Mestiza & 1800 's & Adaptive Reuse \\
\hline 11. & Tiongson House & Bahay Mestiza & 1901 & Adaptive Reuse \\
\hline 12. & Jaconto LomotanHouse & Bahay Mestiza & 1930 & In fair condition \\
\hline 13. & Vicenta TantocoHouse & Bahay Mestiza & No record & Totally Restored \\
\hline 14. & TantocoHouse & Bahay Mestiza & 1800 's & Adaptive Reuse \\
\hline 15. & EstrellaHouse & Demolished & 1940 's & Demolished in 2015 \\
\hline 16. & Lino ReyesHouse & Demolished & 1800 's & Demolished/ Parking \\
\hline 17. & Bautista House & Bahay Mestiza & 1877 & In good condition \\
\hline 18. & Luis SantosHouse & Art Deco & 1933 & Excellent Condition \\
\hline 19. & Alberta Uitangcoy & Bahay Mestiza & 1914 & In good Condition \\
\hline 20. & HermogenesHouse & $\begin{array}{l}\text { On-going demolition/ } \\
\text { adaptive reuse }\end{array}$ & 1904 & $\begin{array}{l}\text { On-going demolition/ adaptive } \\
\text { reuse }\end{array}$ \\
\hline & & & & \\
\hline
\end{tabular}

Table 2 Inventory of Existing Structures in Kamestizuhan District 

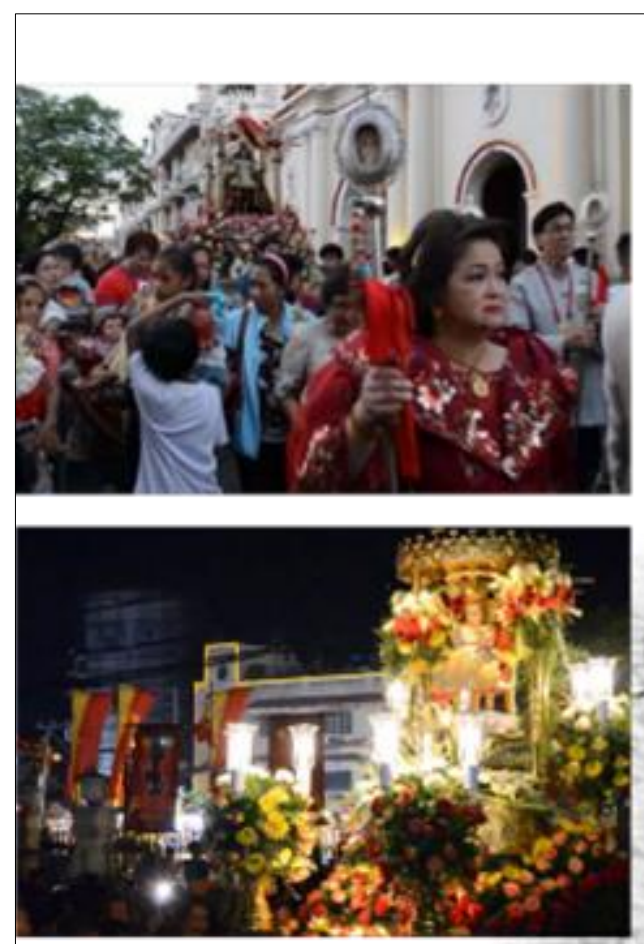

\section{Feasts and Festivals}

Dubbed as the Bulacan's City of Festivals, Malolos boasts with many feasts and festivals every year. Some festivals are civic festivities and most are religious festivals.

Santo Niño de Malolos Festival - This is held during the last Sunday of January, The biggest and largest expression of devotion to the Holy Child Jesus in the Luzon island, celebrated every last Sunday of January. The festivifies begitryith an exhibit of "Santo Niño" (Holy Child) and culminate in a grand procession of hundreds of folk, antique and new statues of the Holy Child in different depictions. The highlight of this festival is the hundred ycar-old antique miraculous image of Senor Sto Nino de Malolos.

Figure 27 The Annual Feast and Festivities in Malolos

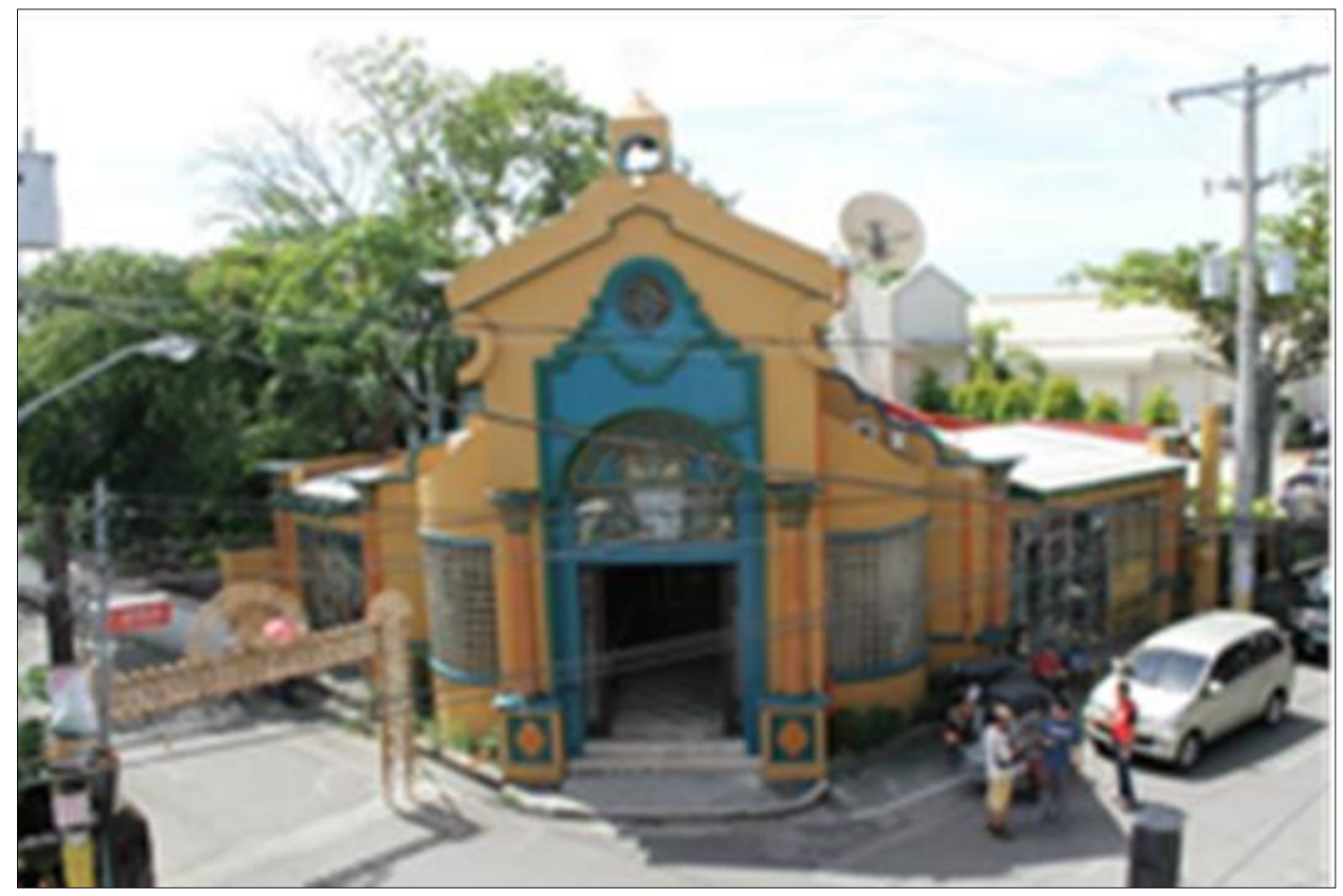

Figure 28 The Santo Niño Chapel

On the same site, the Sto. Nino Chapel has been existing since 1880's. The month of January is one of the most celebrated months in a year in Malolos. The Feast of Sto. Niño de Malolos is a rich week-long cultural celebration showcasing the strong devotions of the people of Malolos. The feast day celebration is being visited tourist and participated by Sto. Nino devotees in the nearby towns and Provinces. 


\section{Community and Cultural Organizations}

The research also mapped out the important community and cultural organizations extant in the district. This is in the belief that civil societies particularly the participated by the locals who are the direct stakeholders are important assets towards successful heritage conservation.

The group identified the following organizations:

\subsection{Women of Malolos Foundation Inc.}

which actively maintains a museum at the Alberta Uitancoy House. During the visit a film is being shot at the house featuring the stories of the 21 Women of Malolos.

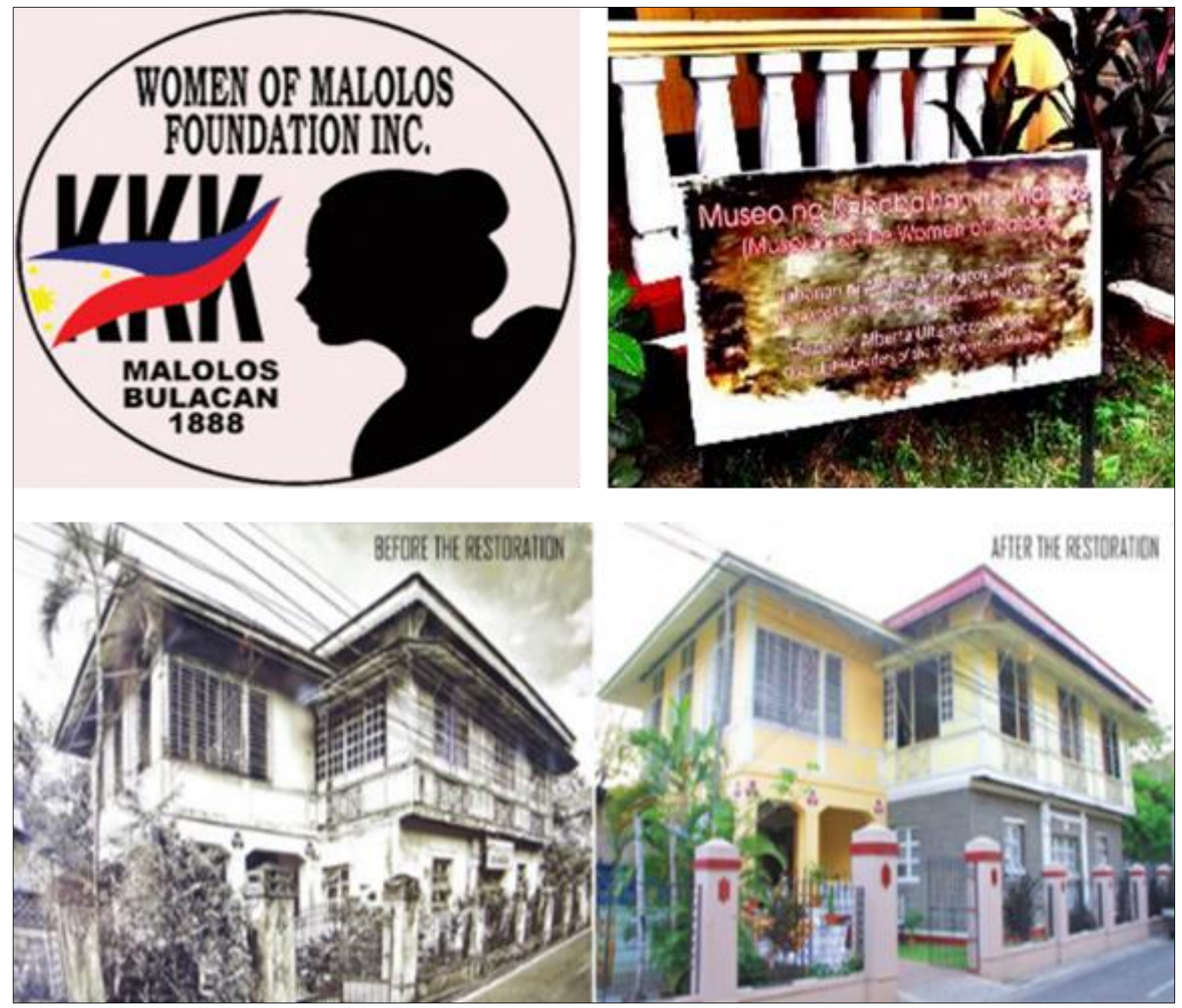

Figure 29 The Local Heritage Organization in Malolos

The Women of Malolos Foundation Inc. located at the Alberta Uitangcoy House. (Alberta Uitangcoy is the Head on the 21 Women of Malolos). 


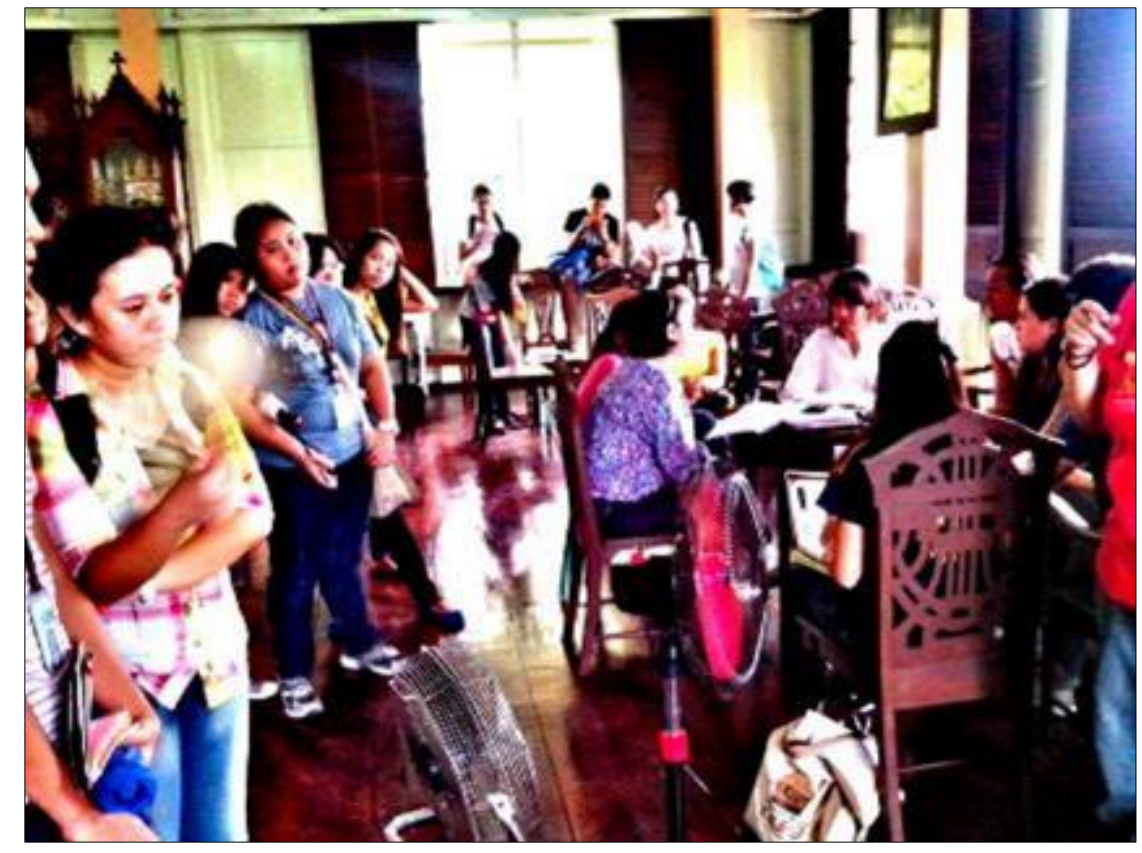

Figure 30 Students and tourists filming in Uitangcoy House

Shooting and Documentaries conducted by students and tourism office and Local Heritage Organizations at the Uitancoy House. Films are seen as important media to amplify heritage education.

\subsection{Sto. Nino Foundation}

Sto. Nino Foundation that facilitates the yearly Sto. Nino de Malolos Festival. The City Government of Malolos has implemented measures favourable to heritage promotion in the district. The mayor has promised that before any house in the district will be sold or demolished a Right of First Refusal is reserved to the City Government. But this promise may be hampered by budgetary constraints.

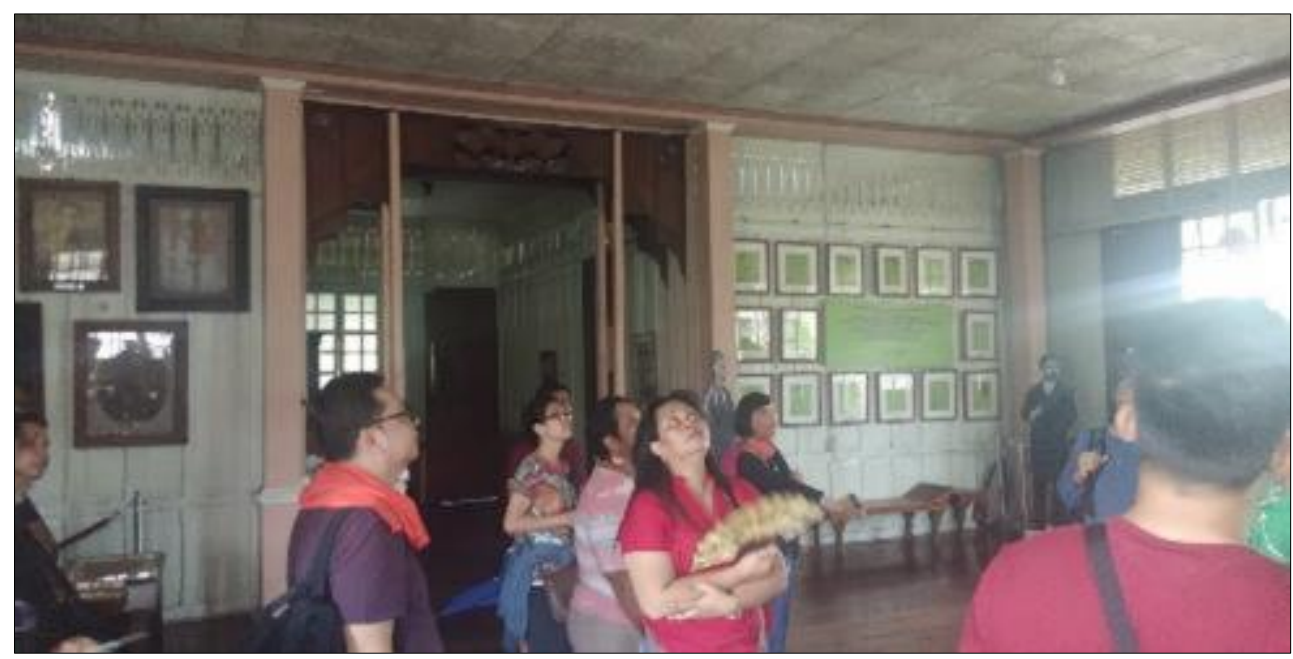

Figure 31 Tourists inside the Uitangcoy House

Heritage tours are also available as a service from the City Tourism Office of Malolos Additionally, the City Tourism Office has recently installed local historical markers to important structures in the district in commemoration of the Malolos Congress anniversary. 


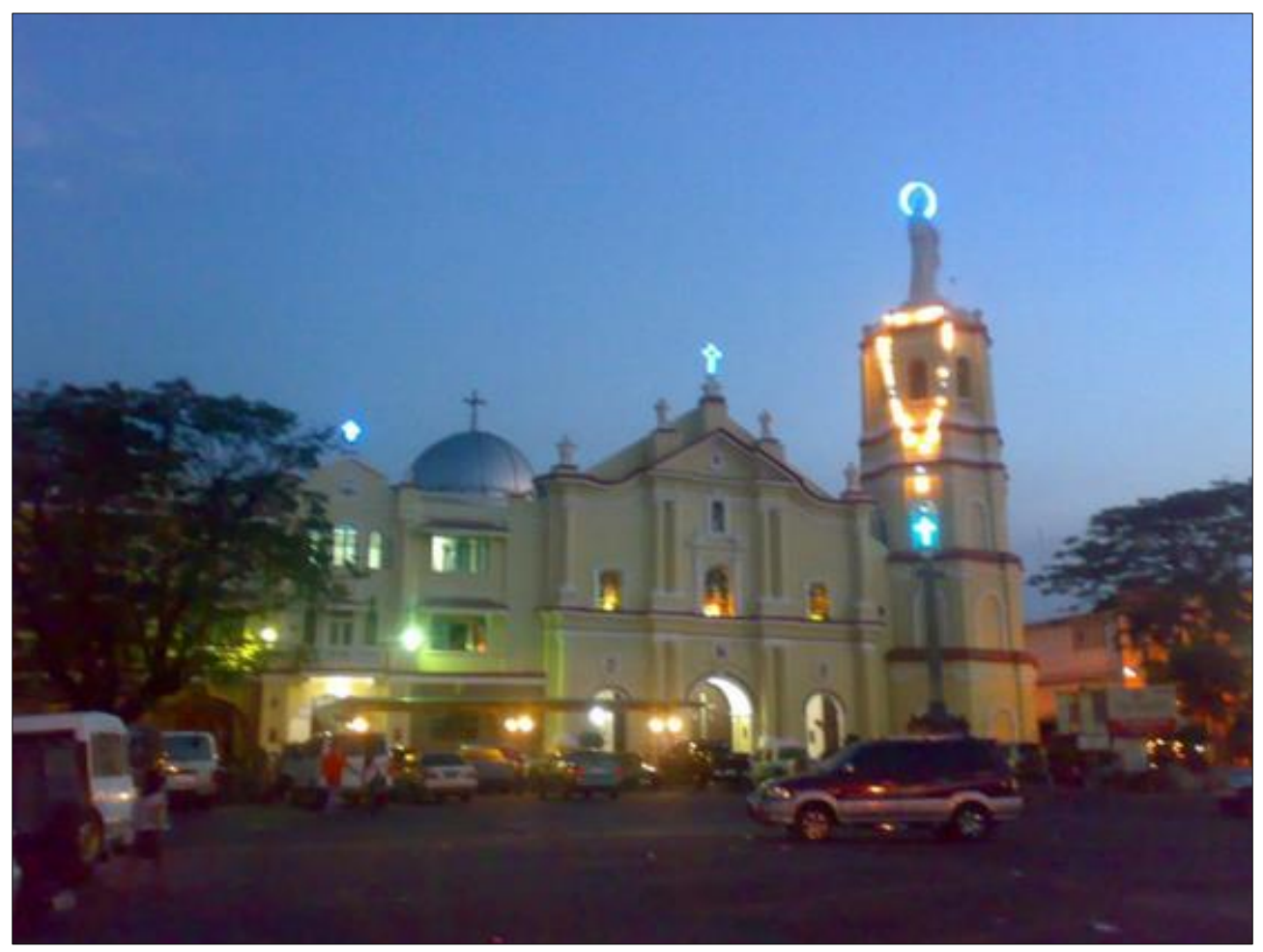

Figure 32 The Malolos Cathedral

Source: www.malolos heritage.com

Museo Diocesano de Malolos, an ecclesiastical art museum housed also at the Barasoain Convent, is managed by the Diocese of Malolos. It houses relics and religious items such as original 19th century baptismal records of Marcelo Hilario (a.k.a. Marcelo H. del Pilar), Francisco Baltazar (a.k.a. Francisco Balagtas) and Gregorio del Pilar; a bone fragment of San Vicente Ferrer encased in glass; priestly robes embroidered with gold-plated silver threads, antique prayer cards and altar frontals from different churches.

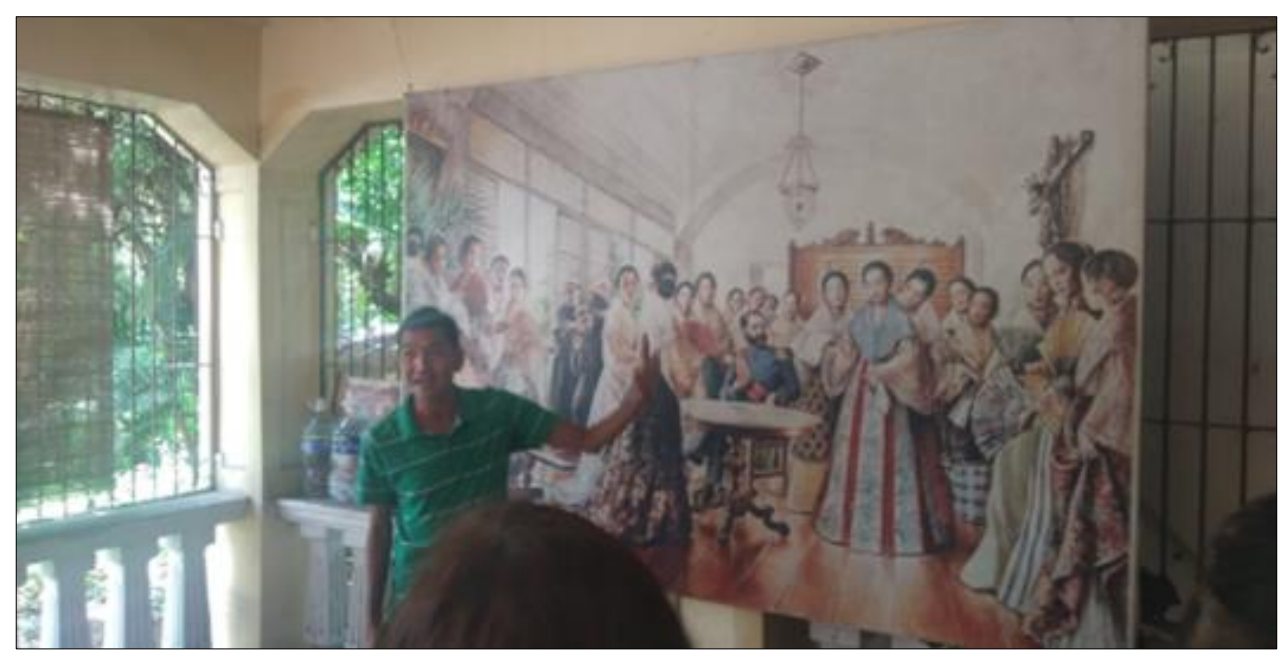

Figure 33 The City Tourism Officer while discussing the 21 Women of Malolos 


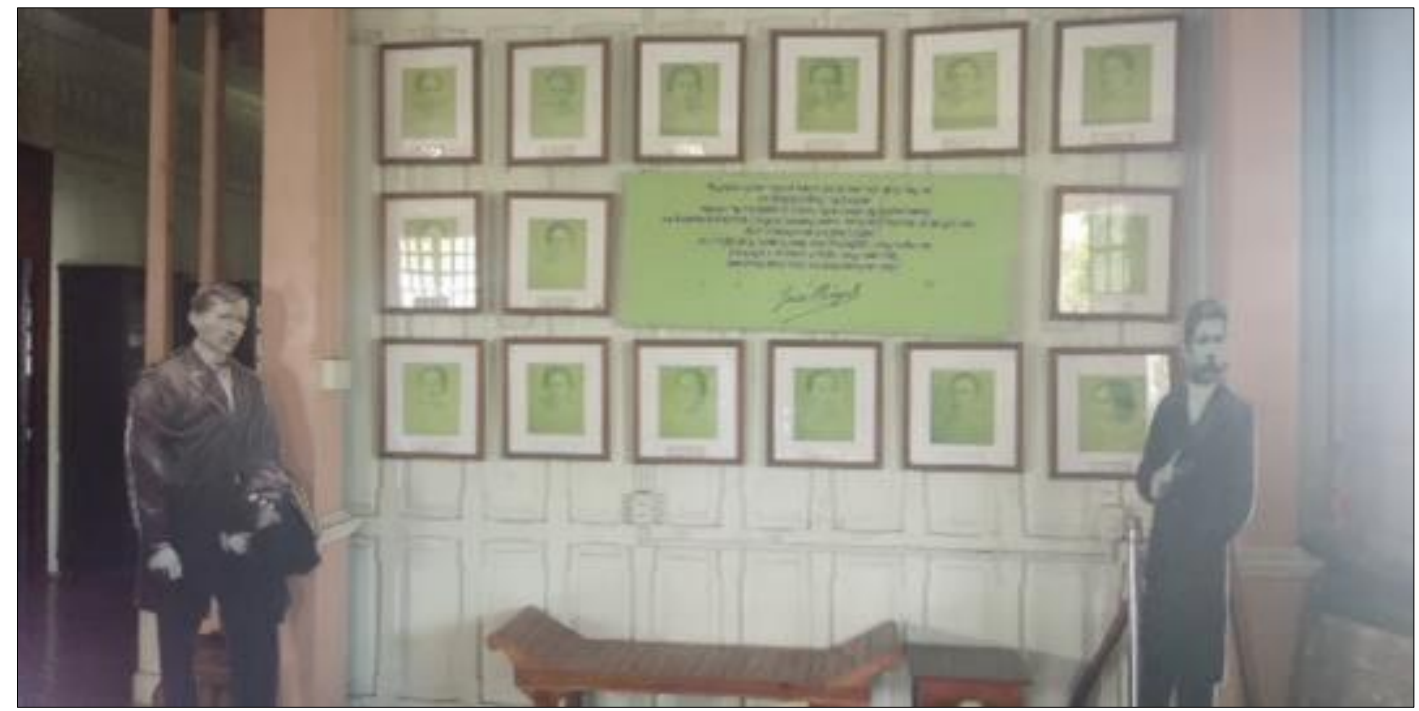

Figure 34 Inside the Uitangcoy-Santos House are the memorabilia of the 21 Women of Malolos

\subsection{Museum of the Women of Malolos}

Museum of the Women of Malolos, found in the Uitangcoy-Santos House, this museum has four exhibit halls and a lecture hall of collections relative to the women's historical narrative. It is curated by the fifth-generation grandson of Alberta Uitangcoy-Santos, Carlo Herrera.

\section{The Historic Twon Center as National Heritage Landmark}

The historic town center of Malolos was declared National Heritage Landmark on August 15, 2001 under the name of Malolos Heritage Town [8].

The mapping project has found the following things:

- That number of intact heritage structures is decreasing.

- The artifacts in the district need to have master list and must properly identified by person in authority.

- There is important intangible heritage like stories of events in national and local histories and even fictive folklores that are related to the district;

- There is a lurking degradation in the physical landscape due to various factors, some are natural and most are anthropogenic. These include but are not limited to demolitions, termite infestation, old age and neglect.

- There is limited governmental support to the conservation of the heritage landscape in the district;

- The civil society such as foundations and organizations should initiate the administration of ways to promote heritage and heritage conservation in the district.

\section{Output of Research Project}

There would be comprehensive and detailed mapping and inventory that will be produced to serve as guide for validation of the remaining cultural heritage of Malolos that still survive amidst the surging urbanization of Malolos. The consolidated local culture profile and generate baseline data for cultural statistics that will recommend mechanisms to integrate profiles and baseline statistics in LGU development plans, programs, and activities[9].

The project relied on various sources of information and data. These include:

- firsthand accounts,

- field observations,

- $\quad$ site visits and photo documentation,

- $\quad$ surveys and

- documentary/archival research. 
The researchers utilized an instrument for Heritage Mapping and Profiling constructed by the National Historical Commission of the Philippines. This form became a useful guide in the organization of questions to be asked from the respondents.

\subsection{The Stages of Cultural Mapping}

The principal output of a cultural mapping activity is a local culture profile. Cultural mapping is an ongoing process. And many of its benefits can only be achieved through sustained efforts to update the cultural data and to compare it over time, which requires continued resources and ongoing partnerships. A cultural mapping project is implemented in distinct phases or stages discussed below.

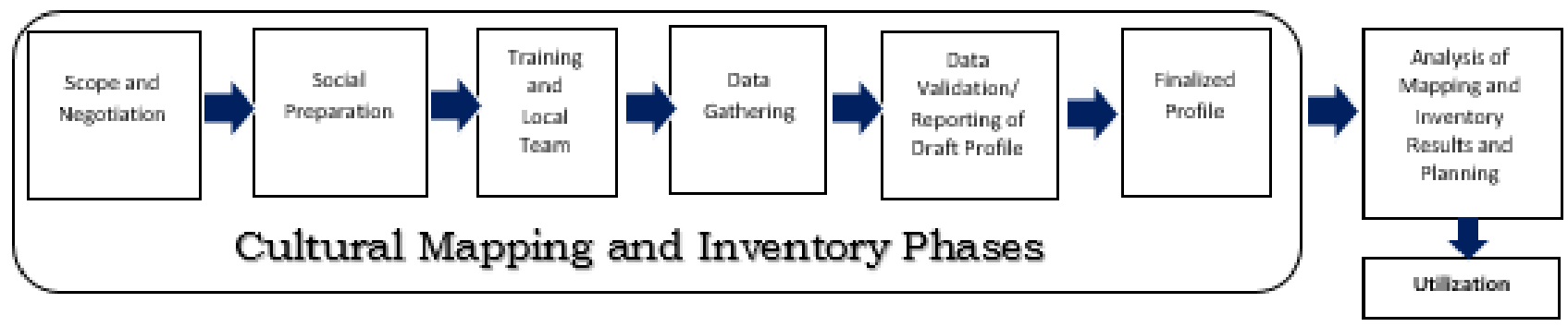

Figure 35 The Cultural Mapping and Inventory Phases

The Scoping and Negotiation Phase involves familiarizing the LGU requesting for the cultural mapping project, discussion of the needed participants, length of the project, and logistical requirements for the project. Basically, it would also be in this phase that the Researchers and the LGU would have to coordinate and establish commitment in the implementation of the project. A Memorandum of Understanding between the NCCA and the LGU shall be accomplished before the start of the cultural mapping project in the locality.

The second phase is the Social Preparation Phase where the LGU shall orient the various stakeholders of the locality of the objectives and processes of the cultural mapping project. They should also brief the intended participants/stakeholders of the project which includes the introduction of the Cultural Mapping Project, identification of mapping teams, identification of needs/logistics/concerns, logistical planning and identification of areas of the locality to be mapped.

The researchers will continue the Data Gathering Phase which will go for about three to six months in order to substantially gather data on the major components of the culture profile depending on the size of the municipality and the number of mappers. Moreover, mappers will be tasked to do actual mapping (i.e. fieldwork and encoding of data) of their assigned cultural properties or practices within the agreed time frame. They must be committed to attend regular monitoring and updating meetings, which would at least be scheduled on a weekly basis.

It will be followed then by the Data Validation, where internal and external experts, stakeholders, and other members of the community will be presented of the data gathered by the mappers or the local mapping team in order to confirm or corroborate the validity of the mapped entries.

The Finalized Local Culture Profile is expected to be produced after the data validation.

The cultural mapping and inventory project ends with the production of the local cultural profile. However, it is important to stress that the results of the cultural mapping should be analyzed in order to draw information that would be useful in the formulation of programs, projects, activities, and policies for culture and arts, hence analysis is included in the diagram of cultural mapping phases. A workshop for the Analysis of the Mapping Results and Planning may be employed [10].

\section{Conclusion}

Malolos Heritage District displays richness in heritage structures particularly the houses of strong significance in Philippine history and played important role in our known heroes. 
The awareness of the local residents in giving importance through conservation of the heritage structures manifested by the houses standing majestically, but evidence of alarming effect of commercialization can also be mirrored in some Spanish and American era houses.

Adaptive reuse is employed and evident in some houses as an attempt to preserve them.

Streets need to be conserved matching with the structures historical characters.

\section{Recommendations}

- Installations of Historical Markers- Historical markers by the National Historical Commission of the Philippines grant protection to heritage structures and give recognition to the heritage of the district and should be lobbied by the community and the local government.

At present there are only two historical markers installed in Pariancillo. One is for the ruins of Instituto Mujeres and the other is in the Meralco Office.

- The Enforcement of the National Cultural Heritage Act of 2009 and the direct participation of the local government.

- The National Cultural Heritage Act of 2009 is also a tool that can be used to assert heritage conservation. The law is liberal in the categorization of heritage structures citing that all 50 years-old and above structures are candidate heritage structures.

- $\quad$ Real Estate Tax Exemptions- For house owners who opted to preserve the structures it is suggested that the government give them tax incentives and if possible, tax exemptions in recognition of the public importance of the structures.

- $\quad$ Local Government-Academe-Industry Partnership (Triple Helix Approach)

- Revitalization of Heritage Tourism through its inclusion in Local History curriculum (Grade 3)

- Creation of Guidelines and Implementing Rules and Regulations

- Barangay officials should have programs on heritage conservations like annual summits, conferences, workshops, etc. to keep them abreast of conservation developments.

- Participation of Academe and Educational campaigns or promotions should be done, especially for the information of the youth sector regarding significance of the heritage district.

\section{Compliance with ethical standards}

\section{Acknowledgments}

The authors would like to express its heartfelt thanks to the Malolos City Mayor and Officials, City Planning and Engineering Officers, local community officials, local and provincial tourism officers, and local heritage organizations. Special thanks also to Bulacan State University College of Architecture and Fine Arts and Research and Management Office and to the entire Bulacan State University Administrators headed by the University President Dr. CeciliaNavasero-Gascon.

\section{Disclosure of conflict of interest}

This research paper underwent the process of screening, checking and monitoring of the Research and Management Office of the Bulacan State University in which the authors duly agreed and understands all the policies and procedures set in the University Research Manual as well as the ethical review administered by the Research Management Office.

\section{References}

[1] Blais, Caroline. Cultural confusions show that facial expressions are not universal. 2009.

[2] Cook, Taylor. A Contemporary Guide to Cultural Mapping. An ASEAN-Australia Perspective, Jakarta, Indonesia. 2013.

[3] National Commission on Culture and Arts, Cultural Mapping Toolkit: A Guide for Participatory Mapping in Local Communities NATIONAL COMMISSION FOR CULTURE AND THE ARTS, 633 General Luna Street, Intramuros, Manila, ISBN 978-621-42-023, 2019. 
[4] Tiongson, Nicanor, Women of Malolos, Ateneo University Press, 2019.

[5] COAWEB Center ICTC Cultural Museum Bulacan Copyright. 2000.

[6] Tiongson, Nicanor, The Women of Malolos, Ateneo de Manila University, Ateneo University Press. 2004.

[7] UNESCO. Cultural policy in the Philippines, A study prepared under the auspice of the UNESCO National Commission of the Philippines, French edition. 1973; 92-3-201133-6.

[8] Malolos City, webpage, Malolos+City+webpage, accessed January 2020.

[9] Manahan GV. Philippine Architecture in the 20th Century, UP College of Architecture, Q.C. 1986.

[10] Cultural Heritage Section, Plan/Policy Formulation and Programming Division, National Commission for Culture and the Arts, 633 Gen. Luna Street, Intramuros, Manila. 1002. 